\title{
Influence of ultra-fine grain structure on corrosion behaviour of biodegradable $\mathrm{Mg}-1 \mathrm{Ca}$ alloy
}

DOI:

10.1016/j.corsci.2019.108303

\section{Document Version}

Accepted author manuscript

Link to publication record in Manchester Research Explorer

\section{Citation for published version (APA):}

Parfenov, E. V., Kulyasova, O. B., Mingo, B., Farrahkov, R. G., Cherneikina, Y. V., Yerokhin, A., Zheng, Y. F., \& Valiev, R. Z. (2020). Influence of ultra-fine grain structure on corrosion behaviour of biodegradable Mg-1Ca alloy. Corrosion Science. https://doi.org/10.1016/j.corsci.2019.108303

\section{Published in:}

Corrosion Science

\section{Citing this paper}

Please note that where the full-text provided on Manchester Research Explorer is the Author Accepted Manuscript or Proof version this may differ from the final Published version. If citing, it is advised that you check and use the publisher's definitive version.

\section{General rights}

Copyright and moral rights for the publications made accessible in the Research Explorer are retained by the authors and/or other copyright owners and it is a condition of accessing publications that users recognise and abide by the legal requirements associated with these rights.

\section{Takedown policy}

If you believe that this document breaches copyright please refer to the University of Manchester's Takedown Procedures [http://man.ac.uk/04Y6Bo] or contact uml.scholarlycommunications@manchester.ac.uk providing relevant details, so we can investigate your claim.

\section{OPEN ACCESS}


Research highlights

- Ultra-fine grain size in $\mathrm{Mg}-1 \mathrm{Ca}$ alloy increases its biodegradation time from days to months

- Continuous nanoprecipitation of $\mathrm{Mg}_{2} \mathrm{Ca}$ improves the corrosion resistance of the UFG alloy

- EIS inductive loop with negative time constant describes this increase in corrosion resistance

- Ultra-fine grained $\mathrm{Mg}-1 \mathrm{Ca}$ alloy is promising for biodegradable implant applications 
Influence of ultra-fine grain structure on corrosion behaviour of biodegradable $\mathrm{Mg}-1 \mathrm{Ca}$ alloy

\author{
E.V. Parfenov ${ }^{1 *}$, O.B. Kulyasova ${ }^{1}$, V.R. Mukaeva ${ }^{1}$, B. Mingo ${ }^{2}$, R.G. Farrakhov ${ }^{1}$, \\ Ya. V. Cherneikina ${ }^{3}$, A. Yerokhin ${ }^{2}$, Y.F. Zheng ${ }^{4}$, R.Z. Valiev ${ }^{1,3}$
}

${ }^{1}$ Ufa State Aviation Technical University, 12 Karl Marx Street, Ufa 450008, RUSSIA

${ }^{2}$ University of Manchester, Oxford Road, Manchester, M13 9PL, UK

${ }^{3}$ Saint Petersburg State University, Universitetskaya nab. 7/9, 199034 Saint Petersburg, Russia

${ }^{4}$ College of Engineering, Peking University, 5 Yi-He-Yuan Road, Hai-Dian District, Beijing 100871, CHINA

\begin{abstract}
Biodegradation studies of $\mathrm{Mg}-1 \mathrm{Ca}$ alloy with different microstructures in Ringer's solution reveal corrosion mechanism based on the balance between the anodic dissolution of the secondary phase and hydroxide precipitation, controlled by the secondary phase size and distribution uniformity. Alloy with ultrafine-grain structure shows at least 5-fold improvement in corrosion resistance compared to the coarse-grained alloy due to the separation of the particles of the secondary phase and its continuous intragranular nano-precipitation. This promotes an unusual low-frequency impedance behaviour described by an inductive loop with the negative time constant, which leads to the increased impedance modulus signifying the improved corrosion resistance.
\end{abstract}

Keywords

magnesium alloy; ultra-fine grained alloy; biodegradable implants; secondary phase; nanoprecipitates; electrochemical impedance spectroscopy

* Corresponding author. Email: evparfenov@mail.ru, pev_us@yahoo.com

Address: 12 Karl Marx Street, Ufa, 450008, RUSSIA, tel. +7 3472721162 


\section{Introduction}

Controllable corrosion behaviour of magnesium alloys underpins the development of advanced biodegradable implants for surgical treatments in traumatology [1]. Being a very active metal, magnesium itself corrodes very fast in the body fluids; therefore, pure Mg implants degrade before the broken bone splices back after the fracture. The reason for this corrosion activity comes out partly of the Pilling-Bedworth ratio signifying how much oxide volume can be formed by conversion of a unit volume of the metal. Unlike $\mathrm{Ti}$ which excellent corrosion resistance is attributed to this ratio being 1.73 , for $\mathrm{Mg}$ it is only 0.81 , indicating this metal cannot form a selfprotecting continuous oxide film [2]. Moreover, low mechanical properties inhibit application of as-supplied $\mathrm{Mg}$ alloys for implant production. Therefore, advanced materials engineering is required in order to produce $\mathrm{Mg}$ biodegradable implant suitable for the surgery. Two approaches can be generally applied to provide improvements in mechanical, physical, chemical and biological properties of $\mathrm{Mg}$ implants. Firstly, magnesium can be alloyed with different species [35]. Secondly, the alloy microstructure can be refined to obtain ultra-fine or nanoscale grain size [6-8]. In this study, both these approaches are explored.

In general, materials exhibiting a typical grain size less than $100 \mathrm{~nm}$ are considered nanostructured; whereas those with the grain size in the range 100 to $1000 \mathrm{~nm}$ are referred to as ultra-fine grained (UFG) [9]. The most common procedure to produce such metallic materials is severe plastic deformation (SPD) [10]. Despite some grains statistically falling out of the specified ranges, those materials also exhibit other structural features in the nanometer scale, e.g. nanotwins, dislocation substructures, segregations and nano-precipitations which are important microstructural elements that provide significant influence on material's properties, including corrosion behaviour [11].

The research is conducted using a new $\mathrm{Mg}-1 \mathrm{Ca}$ alloy produced to enhance osseointegration by the introduction of calcium, which contributes to bone tissue formation during the implant biodegradation $[6,12,13]$. The improvement in mechanical properties, especially fatigue strength, for this alloy can be achieved by the grain refinement, e.g. using high-pressure torsion (HPT) technique [14]. However, this method provides the material ranging from UFG to nanostructured with high internal stresses causing almost zero ductility; the application of further annealing helps to relieve the stresses in the resulting ultra-fine grain structure $[15,16]$. Therefore, development of the UFG structure via SPD followed by annealing can provide a unique combination of mechanical properties including high strength and significant ductility simultaneously. Moreover, recent studies of nanostructuring for another $\mathrm{Mg}$ alloys showed improvement of the corrosion properties as well [17, 18]. 
Although there are several studies into corrosion resistance of $\mathrm{Mg}$-Ca alloys, the influence of this alloying element is not completely clear. It has been reported repeatedly that $\mathrm{Ca}$ incorporation may increase the corrosion rate due to precipitation of $\mathrm{Mg}_{2} \mathrm{Ca}$ intermetallic particles that promote galvanic corrosion [19-21]. However, there is no clear agreement on the role of $\mathrm{Mg}_{2} \mathrm{Ca}$ secondary phase in this process; some authors consider it behaves anodically with respect to the magnesium matrix $[19,22,23]$, while others believe it provides cathodic effect $[21,24]$. Mohedano et al [25] observed a negligible potential difference between the two phases suggesting that no micro-galvanic corrosion would occur. Moreover, several authors observed a positive influence of $\mathrm{Ca}$ on the corrosion resistance of binary $\mathrm{Mg}$-Ca alloys. Zeng et al [26] found that $\mathrm{Ca}$ plays a dual role whereby the increase in Ca content refines the grain size, improving the corrosion resistance, although the total length of $\mathrm{Mg}_{2} \mathrm{Ca} / \mathrm{Mg}$ grain boundaries increases, decreasing the corrosion resistance. Bornapour et al [27] observed that the weight loss of an cast $\mathrm{Mg}-\mathrm{Ca}$ (0.6 wt. \%) alloy was reduced nearly $80 \%$ compared to pure $\mathrm{Mg}$. Wan et al [28], when studying the corrosion behaviour of different cast $\mathrm{Mg}-\mathrm{Ca}(0-2 \mathrm{wt}$. \% $\mathrm{Ca}$ ) alloys, observed a positive influence of $\mathrm{Ca}$ in terms of polarisation resistance. Both works mainly attributed such improvement to the formation of more compact layers of stable corrosion products that provide further corrosion protection. A simulation work by Velikohatnyi et al [29] is in complete agreement with this theory. By evaluating the cohesive energy as a measure of the overall chemical stability of corrosion products for different $\mathrm{Mg}$ alloys with several alloying elements (Ca, $\mathrm{Zn}, \mathrm{Al}$, $\mathrm{Y}$ and $\mathrm{Fe}$ ), it demonstrated that $\mathrm{Ca}$ increases the cohesive energy, promoting the formation of more stable and less reactive hydroxide layer. Li et al [30] evaluated three $\mathrm{Mg}-1 \mathrm{Ca}$ alloys in cast, rolled and extruded form and observed an improvement in the corrosion resistance as the grain size decreased. This was attributed to the enhanced protective properties of the semi-passive layer. Such a broad diversity of opinions regarding the effects of $\mathrm{Ca}$ on the overall corrosion resistance of binary $\mathrm{Mg}$-Ca alloys indicates the need for further research to elucidate the role of this alloying element.

Recent research employing potentiodynamic polarisation (PDP), electrochemical impedance spectroscopy (EIS), weight change and hydrogen evolution assessments shows significant progress in understanding the mechanisms underlying $\mathrm{Mg}$ alloy biodegradation [3133]. Nevertheless, interpretation of the EIS results, especially at the lowest frequency end, and the corrosion mechanisms are still disputed [31, 33-35]. Moreover, the role of the secondary phase and alloy impurities has been investigated and corresponding corrosion galvanic cells were assessed [36, 37]. However, certain important issues are missing in the consideration of $\mathrm{Mg}$ corrosion mechanisms, especially, the role of $\mathrm{Mg}$ alloy nanostructuring and grain refinement in the corrosion mechanism has not been revealed in details [38, 39]. 
Therefore, the goal of this research is to reveal microstructure dependent aspects of controllable biodegradation for the new $\mathrm{Mg}-1 \mathrm{Ca}$ alloy.

\section{Experimental}

2.1. Alloy nanostructuring

A binary $\mathrm{Mg}-1 \mathrm{Ca}$ alloy in the cast condition was used in this study. In order to eliminate the effects of dendritic segregation, the as-supplied cast ingots were homogenised at $450 \pm 5^{\circ} \mathrm{C}$ for 12 hours. The alloy was heat treated in a Nabertherm muffle furnace. The heat treatment was performed for the alloy ingots in air. The surface oxide layer formed during homogenisation was subsequently removed with sandpaper and the ingots were then wire-cut into samples using electric discharge machining. To produce nanostructured samples, $20 \mathrm{~mm}$ diameter disks with a thickness of $1 \mathrm{~mm}$ were subjected to high-pressure torsion treatment at room temperature using the method described elsewhere [15]. The applied pressure was $6 \mathrm{GPa}$, and to refine the structure, 10 revolutions were made. To assess the effect of the grain size, the nanostructured samples were annealed at $250 \pm 5^{\circ} \mathrm{C}$ for 6 hours. This heat treatment provided ultrafine-grained structure in the samples. Thus, three types of the alloy were assessed: coarse-grained, nanostructured (nanocrystalline) and ultrafine-grained, denoted further in the text as CG, NC and UFG respectively. The treatment routine for the grain size variation is summarised in Fig. 1.

Different batches of the same material possess different amounts of impurities (e.g. Fe, $\mathrm{Mn}, \mathrm{Cu}$ and $\mathrm{Ni}$ ), which are known to affect the corrosion behaviour of $\mathrm{Mg}$. To control the influence of impurities in this work, the same ingot which served as a source of the CG samples was used for the HPT treatment and further annealing to produce the NC and UFG samples. In this case, the effect of impurities was assumed to be similar for all the samples and the sole influence of the ultra-fine grain refinement could be revealed.

The samples were polished using SiC grinding paper from 600 to 2000 grit to achieve roughness $\mathrm{Ra}=0.10 \pm 0.02 \mu \mathrm{m}$. For the scanning electron microscopy (SEM), the surface was polished using diamond paste and $\mathrm{Al}_{2} \mathrm{O}_{3}$ suspension to achieve mirror polish. For the transmission electron microscopy (TEM), the foils were prepared by electrolytic polishing under $14 \mathrm{~V}$ polarisation in solution containing $30 \mathrm{wt} \%$ nitric acid and $70 \mathrm{wt} \%$ methanol, using a Tenupol-5 system.

\subsection{Alloy characterisation}

The alloy macro- and microstructure were studied using JEOL JSM-6490LV scanning electron microscope and JEM-2100 transmission electron microscope at accelerating voltages of $10 \mathrm{kV}$ and $200 \mathrm{kV}$ respectively. The elemental analysis was assessed during the SEM with an EDS 
attachment INCAX-Sight. Because the alloy structure after HPT depends on the distance from the rotation centre, the structural characterisation was made at a half radius of the sample. The SEM and TEM images were processed using ImageJ software. The grain size was measured according to ASTM E112-10 standard. The grayscale images were levelled via a threshold to produce black and white images further used to calculate the percentage of the surface area that belongs to the black objects standing for the eutectics and the secondary phase. At least 15 images were analysed in order to have a reliable estimate.

The phase composition of the surface layer was characterised by X-ray diffractometer Rugaku Ultima IV in $\mathrm{Cu} \mathrm{K \alpha}$ radiation at $40 \mathrm{kV}$ and $40 \mathrm{~mA}$ using $0.02 \mathrm{deg}$. step scan with $2 \mathrm{~s}$ exposure, from 20 to 80 degrees $2 \theta$. Further, the XRD spectra were processed using Philips X'Pert Highscore Plus software with PDF2 pattern database. The microstrain was calculated from the XRD profiles using the Williamson-Hall method [40]. Rietveld analysis was employed in order to evaluate the quantitative amount of the crystalline secondary phase in the alloy by applying Structure Fit kernel within the Rietveld Algorithm realised in the X'Pert Highscore Plus software [41]. The crystal structure data for $\alpha-\mathrm{Mg}$ and $\beta-\mathrm{Mg}_{2} \mathrm{Ca}$ was obtained from the Crystallography Open Database [42].

A Bruker Multimode 8-HR Atomic Force Microscope (SKPFM) was used to obtain the surface potential maps (also known as Volta potential maps) of the studied alloys. This technique is especially useful for bridging with corrosion studies because it provides localised electrochemical information for identifying potential corrosion initiation points. It has been used previously to determine the electrochemical activity of corrosion products in other types of alloys. For instance, K.A.Yasakau et al [43] used SKPFM to observe changes in electrochemical activity of grain boundaries in galvanised zinc coatings due to precipitation of corrosion products. The specimens for characterisation were polished $24 \mathrm{~h}$ prior to the measurement and kept in a desiccator to avoid partial oxidation. Corroded specimens were analysed after $24 \mathrm{~h}$ of atmospheric exposure. Ideally, these measurements should have been made after $24 \mathrm{~h}$ of immersion in Ringer's solution; however, the presence of large amounts of heterogeneous corrosion products did not allow SKPFM scanning to be performed. Therefore, a less aggressive environment, where fewer corrosion products are formed, was chosen to characterise the corrosion response with this method. The scanning was carried out using a PFQNE-AL Bruker Silicon tip working in tapping mode at a constant tip-to-sample distance of $150 \mathrm{~nm}$ and at a scanning rate of 0.1-0.2 Hz. All measurements were acquired at $22 \pm 1^{\circ} \mathrm{C}$ and $60-65 \%$ relative humidity. The profiles were analysed using the Nanoscope Analysis software; at least 10 profiles were analysed in order to obtain the average values of the potential difference. 


\subsection{Corrosion evaluation}

Corrosion properties were assessed using weight loss and electrochemical techniques. The sample weight was measured using analytical balance GR-200 (A\&D, Japan) with an accuracy of $0.1 \mathrm{mg}$. The samples were immersed into $50 \mathrm{ml}$ of Ringer's solution $(0.86 \% \mathrm{NaCl}, 0.03 \% \mathrm{KCl}$, $0.033 \% \mathrm{CaCl}_{2}, \mathrm{pH} 7.4$ ) for 32 days at $37 \pm 2{ }^{\circ} \mathrm{C}$; periodically, the samples were taken out and weighted; the solution was changed every 7 days. The resulting sample weight change was considered affected by both metal loss and mass gain due to precipitation of corrosion products.

The electrochemical tests were carried out also in Ringer's solution at temperature $37.0 \pm 0.2{ }^{\circ} \mathrm{C}$ using P-5X (Elins, Russia) electrochemical system. The corrosion cell was a $100 \mathrm{ml}$ thermostatic glass vessel filled with $80 \mathrm{ml}$ of the Ringer's solution; the reference electrode was a silver chloride electrode filled with a saturated $\mathrm{KCl}$ solution $(+0.220 \mathrm{~V}$ vs standard hydrogen electrode); the counter electrode was a platinum rod. The surface area of the sample exposed to the electrochemical test was $4.6 \mathrm{~cm}^{2}$. After the open circuit potential (OCP) was settled within \pm $20 \mathrm{mV}$ for at least 30 minutes, the electrochemical impedance spectroscopy (EIS) was performed from $100 \mathrm{kHz}$ to $1 \mathrm{mHz}$ with the magnitude of $10 \mathrm{mV}$ around the OCP.

The EIS results were analysed using ZView software from Scribner Associates [44]. Linear Kramers-Kronig check using the procedure described elsewhere [45] had shown that the selected data could be described with a reasonable number of Voight R-C pairs; therefore, the data was KK-transformable.

The potentiodynamic polarisation test was run from $-300 \mathrm{mV}$ to $+300 \mathrm{mV}$ with respect to the OCP value at a rate of $0.25 \mathrm{mV} / \mathrm{s}$. The apparent $i_{\text {corr }}$ values have been derived from the Tafel regions of cathodic parts of the PDP curves at the intersection of the cathodic tangent line with the level of $E_{\text {corr }}$. The polarisation resistance was obtained using the polarisation curve slope at $\pm 10 \mathrm{mV}$ around zero overpotential [46].

Three identical samples for every alloy structure were used; the properties were correspondingly averaged, and the most representative plots were chosen for the figures in this paper.

\section{Results}

When discussing the influence of microstructure on corrosion behaviour of the studied $\mathrm{Mg}-1 \mathrm{Ca}$ alloys, it would be logical to align the experimental results with the grain size - from CG to UFG and NC - rather than the treatment routine (Fig. 1); all figures and tables in this section are therefore arranged following this pattern. 


\subsection{Alloy structure}

Fig. 2 shows the structure of CG, UFG and NC Mg-1Ca alloy. The microstructure of CG $\mathrm{Mg}-1 \mathrm{Ca}$ alloy after homogenisation (Fig. 2a) contains equiaxial grains with the average size $\mathrm{Dg}=42 \pm 3 \mu \mathrm{m}$; moreover, some grains reach $200 \mu \mathrm{m}$ in diameter. EDS tests which results are shown in Table 1 for points 1 and 2 in Fig. 2 b show the presence of two phases; this is consistent with previous observations [25, 47]. From the $\mathrm{Mg}$-Ca phase diagram and from the X-Ray diffractometry results (Fig. 3), these phases can be identified as $\alpha-\mathrm{Mg}$ solid solution and $\beta_{\mathrm{I}}-\mathrm{Mg}_{2} \mathrm{Ca}$ particles of the secondary phase $[6,48]$. Since these particles appear due to solidification and further annealing of the primary ingot, we shall refer them to as stationary $\beta_{\mathrm{I}}-\mathrm{Mg}_{2} \mathrm{Ca}$. Point 1 corresponds to the equiaxial grains of the $\alpha$-solid solution of $\mathrm{Ca}$ in magnesium matrix. Point 2 corresponds to $\beta_{\mathrm{I}}-\mathrm{Mg}_{2} \mathrm{Ca}$ secondary phase which volume fraction is $6.6 \%$ (Table 2).

High-pressure torsion processing provides significant grain refinement; TEM study shows that the average grain size Dg reaches $100 \pm 9 \mathrm{~nm}$ (Fig. 2f). The nanostructure exhibits high dislocation density and high internal stresses induced by severe shear strains under high pressure; this is supported by the increase in microstrain and decrease in cell parameters of $\mathrm{Mg}$ matrix (Table 2). Moreover, since the high dislocation density is an important factor affecting the corrosion behaviour, it is expected that the $\mathrm{NC}$ alloy should behave differently compared to $\mathrm{CG}$. The stationary particles of $\beta_{\mathrm{I}}-\mathrm{Mg}_{2} \mathrm{Ca}$ phase can be observed in the SEM images of the NC samples as curved contours (Fig. 2e); their total volume fraction and weight percent decreased compared to the CG structure (Table 2). Apparently, a certain part of $\mathrm{Ca}$ is dissolved in the $\mathrm{Mg}$ matrix of the NC samples under the high pressure.

SEM study of UFG sample structure after HPT and additional annealing reveals the presence of $\beta_{\mathrm{I}}-\mathrm{Mg}_{2} \mathrm{Ca}$ stationary phase particles, with a volume fraction of $2.3 \%$ (Fig. 2c). TEM study (Fig. 2d) of the microstructure shows low dislocation density; this is consistent with the decrease of the microstrain compared to the NC alloy (Table 2). The average grain size Dg is evaluated as $1.1 \pm 0.2 \mu \mathrm{m}$. Also, Fig. 2d shows nano-precipitates of the secondary phase with the average size of $70 \mathrm{~nm}$. We shall refer to these nano-precipitates as $\beta_{\mathrm{II}}-\mathrm{Mg}_{2} \mathrm{Ca}$, since they appear due to the solid solution decomposition in the NC alloy during the annealing; and they have the volume fraction of $3.6 \%$. The total volume fraction of the secondary phase for the UFG alloy is $5.9 \%$.

As follows from Table 2, the weight fraction of $\mathrm{Mg}_{2} \mathrm{Ca}$ decreases from $3 \%$ for $\mathrm{CG}$ to $1.3 \%$ for the NC sample. Both volume and weight fractions exhibit the same behaviour, and they decrease with the grain size decrease. From Fig. 2d, it also follows that only UFG structure exhibits $\beta_{\mathrm{II}}-\mathrm{Mg}_{2} \mathrm{Ca}$ nano-precipitates within the $\alpha-\mathrm{Mg}$ grains. Considering that the majority of the 
secondary phase appears within the grain boundaries for CG and $\mathrm{NC}$ alloy, the corrosion behaviour for the UFG alloy should differ from that of CG and NC.

Fig. 4 shows the surface potential maps obtained by SKPFM of $\mathrm{Mg}_{2} \mathrm{Ca}$ secondary phase of the studied alloys. For the three alloy structures, it was revealed that the secondary phase $\mathrm{Mg}_{2} \mathrm{Ca}$ is anodic with respect to the $\alpha-\mathrm{Mg}$ matrix with the potential difference $\Delta \mathrm{V}$ between -30 and -100 $\mathrm{mV}$ (Table 3). This anodic behaviour was expected given the lower standard potential of $\mathrm{Ca}$ $\left(-2.87 \mathrm{~V}_{\mathrm{SHE}}\right)$ compared to that of $\mathrm{Mg}\left(-2.37 \mathrm{~V}_{\mathrm{SHE}}\right)$. These values are in accordance with other works [49]. The values of the potential difference depend on the processing route; this is associated with the total amount of $\mathrm{Mg}_{2} \mathrm{Ca}$ volume and mass fractions, with the uniformity of their distribution, and with the presence of the nano-precipitates. After the HPT (NC samples), the total amount of $\mathrm{Mg}_{2} \mathrm{Ca}$ decreases (Table 2) due to Ca diffusion into the $\alpha$-Mg matrix. Greater amounts of $\mathrm{Ca}$ in the solid solution result in the overall decrease of the surface potential of the $\alpha-\mathrm{Mg}$ matrix and, consequently, to lower surface potential difference $\Delta \mathrm{V}$ between $\alpha-\mathrm{Mg}$ and $\beta-\mathrm{Mg}_{2} \mathrm{Ca}$. After annealing (UFG samples), the surface potential difference also decreases compared to that observed in the NC sample, because of the formation of $\beta_{\mathrm{II}}-\mathrm{Mg}_{2} \mathrm{Ca}$ nanoprecipitates within $\alpha-\mathrm{Mg}$ grain bodies. These nano-precipitates are uniformly distributed over the alloy matrix, and their presence decreases further the surface potential difference between $\alpha-\mathrm{Mg}$ and $\beta_{\mathrm{I}}-\mathrm{Mg}_{2} \mathrm{Ca}$ located within the grain boundaries.

\subsection{Material weight changes due to corrosion}

Fig. 5 shows the appearance of the samples during the immersion test. The CG samples disintegrate after four days of the test. Their surface is covered with a white loose layer of corrosion products. The remains of the samples feature thorough holes from the pitting corrosion. Both UFG and NC samples withstood 32 days of the test without disintegration. As seen in Fig. 5, the NC samples exhibited predominantly pitting corrosion with the formation of corrosion products following by development of through holes, while the UFG samples showed arcs of corrosion products built up, following the rotation lines during the HPT treatment. This is consistent with the secondary phase distribution. For the $\mathrm{NC}$ samples, $\beta_{\mathrm{I}}-\mathrm{Mg}_{2} \mathrm{Ca}$ phase appears as curved contours that would likely to promote the pitting corrosion. For the UFG samples, the effect of $\beta_{\mathrm{II}}-\mathrm{Mg}_{2} \mathrm{Ca}$ nano-precipitates can be lower where the rotation lines are left by the HPT plungers; a similar influence of $\mathrm{Mg}$ alloy texture was found elsewhere [50].

Fig. 6 shows the sample weight change during the immersion test. The weight change appears to be a linear function of the immersion time and for the CG samples, it has the highest rate of $-0.94 \mathrm{~g} \cdot \mathrm{dm}^{-2} \cdot \mathrm{day}^{-1}$. The NC samples gained some weight at a rate of $0.057 \mathrm{~g} \cdot \mathrm{dm}^{-2} \cdot \mathrm{day}^{-1}$, while the UFG samples kept it almost constant at a rate of $-0.052 \mathrm{~g} \cdot \mathrm{dm}^{-2} \cdot \mathrm{day}^{-1}$. 


\subsection{Surface morphology following corrosion attack}

Fig. 7 shows top views of the samples with corrosion damage incurred after $24 \mathrm{~h}$ of exposure in Ringer's solution. The CG samples developed massive lumps of corrosion products separated with significant cracks, probably along the grain boundaries. Similar lumps but with much smaller size were also observed on the surface of UFG samples, together with some needlelike crystals; this is consistent with other studies [35, 51]. For the NC samples, the amount of the lumps was significantly smaller, and the number of needle-like crystals increased.

Fig. 8 shows surface potential maps and profiles of the partially corroded $\mathrm{Mg} 1-\mathrm{Ca}$ alloy with CG, UFG and NC structures. Unlike uncorroded specimens (Fig. 4), the secondary phase gains a positive potential difference compared to the alloy matrix. This is related to the precipitation of corrosion products on the surface of the $\mathrm{Mg}_{2} \mathrm{Ca}$ secondary phase, which are cathodic compared to the $\alpha-\mathrm{Mg}$ matrix. All specimens showed a wide range of values, due to compositional heterogeneities, starting at approximately $70 \mathrm{mV}$ and reaching values of up to 400 $\mathrm{mV}$ for the CG structure. UFG and NC alloys showed lower upper limits of 135 and $240 \mathrm{mV}$ respectively. The potential differences shown in Table 3 indicate that the new active cathodes have been formed in all alloys, with those in the CG structure being the most intense.

\subsection{Electrochemical corrosion behaviour}

Fig. 9 shows the results of the potentiodynamic polarisation test for the $\mathrm{Mg}-1 \mathrm{Ca}$ alloy samples with CG, UFG and NC structure. The $E_{\text {corr }}$ values (Table 4) range from -1.46 to $-1.51 \mathrm{~V}$ vs. $\mathrm{AgCl}$, with the highest and the lowest values attributed to the UFG and CG alloys respectively, showing that all surfaces are rather active. The PDP curves show Tafel regions only under cathodic polarisation; the anodic parts do not follow linear dependencies within 0 to $200 \mathrm{mV}$ overpotentials. Therefore, only cathodic slopes $\beta_{c}$ can be considered, and the apparent $i_{\text {corr }}$ values can be only estimated at the intersection of the cathodic tangent line and $E_{\text {corr }}$ value. The apparent $i_{\text {corr }}$ for the samples range from 3.1 to $53.3 \mu \mathrm{A} \mathrm{cm}^{-2}$, showing the lowest value for the UFG alloy, and the highest for the CG. The obtained values of corrosion current density are lower compared to those obtained by Bornapour et al [27] on cast binary and ternary alloys $\mathrm{Mg}-0.5 \mathrm{Sr}$ $\left(5.0 \mathrm{~mA} \mathrm{~cm}{ }^{-2}\right), \mathrm{Mg}-0.6 \mathrm{Ca}\left(4.01 \mathrm{~mA} \mathrm{~cm}^{-2}\right), \mathrm{Mg}-0.3 \mathrm{Sr}-0.3 \mathrm{Ca}\left(6.3 \mathrm{~mA} \mathrm{~cm}{ }^{-2}\right)$ and $\mathrm{Mg}-0.5 \mathrm{Sr}-0.6 \mathrm{Ca}$ $\left(5.6 \mathrm{~mA} \mathrm{~cm}^{-2}\right)$; and by Li et al [30] on cast $\left(\sim 547 \mathrm{~mA} \mathrm{~cm}^{-2}\right)$, rolled $\left(\sim 71 \mathrm{~mA} \mathrm{~cm}^{-2}\right)$ and extruded $\left(\sim 75.8 \mathrm{~mA} \mathrm{~cm}^{-2}\right) \mathrm{Mg}-1 \mathrm{Ca}$ alloys. It should be noted that the anodic parts of the PDP curves show little difference among all the alloy structures, and vary within the experiment error. The polarisation resistance follow the dependency of the corrosion current: $R_{p}$ has the highest value for 
the UFG alloy; this is approximately 25 times higher compared to data reported in other works performed on cast Mg-0.6Ca alloys [28].

The impedance spectra are presented in Fig. 10 in the form of complex and Bode plots. The data were fitted with the equivalent circuit (EC) presented in Fig. 11, with fit results collated in Table 5. The values of electrolyte resistance $R_{s}$ were averaged for all samples for the sake of consistency. All complex plots in Fig 10 feature two conjoined semicircles in the upper half-plane, suggesting a presence of two relaxation processes. In the lower half-plane, the spectra also include an inductive response; this is typical for the $\mathrm{Mg}$ alloy corrosion [32]. The lowest frequency end of the spectra exhibits scattering at the frequencies below $\sim 0.01 \mathrm{~Hz}$; this suggests that the system at test voltage cycles $>100 \mathrm{~s}$ tends to become non-stationary. Moreover, UFG and NC samples show unusual behaviour of the EIS spectra at the lowest frequencies. Instead of decreasing, as for the CG samples, the impedance modulus increases, suggesting (i) better corrosion protection and (ii) negative time constant in the inductive response part.

\section{Discussion}

4.1. Corrosion mechanism of Mg-Ca alloy in Ringer's solution

As shown above, the secondary phase and the $\alpha-\mathrm{Mg}$ matrix form a galvanic corrosion cell with a significant potential difference ranging from 32 to $98 \mathrm{mV}$ (Table 3) which is in a good agreement with the value of $100 \mathrm{mV}$ obtained elsewhere [36]. Therefore, two anodic reactions occur over the surface of the electronegative secondary phase, resulting in its anodic dissolution (Fig. 12a):

$$
\begin{array}{ll}
\mathrm{Mg}^{0}-2 \mathrm{e}^{-} \rightarrow \mathrm{Mg}^{2+} & \left(-2.37 \mathrm{~V}_{\mathrm{SHE}}\right) \\
\mathrm{Ca}^{0}-2 \mathrm{e}^{-} \rightarrow \mathrm{Ca}^{2+} & \left(-2.87 \mathrm{~V}_{\mathrm{SHE}}\right)
\end{array}
$$

Since the Ringer's solution is a $\mathrm{pH}$ neutral environment, based on the Pourbaix diagram of $\mathrm{Mg}$ [52] the cathodic reaction is:

$$
2 \mathrm{H}_{2} \mathrm{O}+2 \mathrm{e}^{-} \rightarrow \mathrm{H}_{2}+2 \mathrm{OH}^{-} \quad\left(-0.83 \mathrm{~V}_{\mathrm{SHE}}\right) .
$$

The secondary phase acts as the anode in the galvanic cell, thus, providing some cathodic protection for the surface of the electropositive $\alpha-\mathrm{Mg}$ matrix. This process differs from the mechanisms described elsewhere $[31,32]$ that consider secondary phases as noble particles; this is true for the majority of $\mathrm{Mg}$ alloys, except for $\mathrm{Mg}-\mathrm{Ca}$, and, as authors can suggest, for $\mathrm{Mg}-\mathrm{Sr}$ and Mg-Li systems.

During the immersion test, the samples gained a layer of the corrosion products (Fig. 7). In neutral $\mathrm{pH}$ range, the corrosion products such as $\mathrm{Mg}(\mathrm{OH})_{2}$ and $\mathrm{Ca}(\mathrm{OH})_{2}$ are mainly formed via the following reactions from the alloy constituents, $\mathrm{Mg}$ and $\mathrm{Ca}$ (Fig. 12b):

$$
\mathrm{Mg}+2 \mathrm{H}_{2} \mathrm{O} \rightarrow \mathrm{Mg}(\mathrm{OH})_{2} \downarrow+\mathrm{H}_{2} \uparrow
$$




$$
\mathrm{Ca}+2 \mathrm{H}_{2} \mathrm{O} \rightarrow \mathrm{Ca}(\mathrm{OH})_{2} \downarrow+\mathrm{H}_{2} \uparrow
$$

These hydroxide corrosion products have low solubility [53] (Table 6); therefore, they become deposited on the surface, appearing as lumps with cracks [35] found in Fig. 7. These hydroxide deposits appear first at the sites with higher activity, such as secondary phase particles and $\mathrm{Mg}$ grain boundaries (Fig. 12b), and later on, expand over the complete metal surface (Fig. 12c). SKPFM studies revealed that the layer of corrosion product formed over the $\mathrm{Mg}_{2} \mathrm{Ca}$ phase at the initial stage of the corrosion process appears to be cathodic with respect the $\alpha-\mathrm{Mg}$ matrix (Table 3). Therefore, the microgalvanic corrosion is likely to take place at the interface between the corroded $\mathrm{Mg}_{2} \mathrm{Ca}$ particle and $\alpha-\mathrm{Mg}$ matrix, but this time the matrix is dissolved predominantly due to its anodic behaviour with respect to the corrosion products covering the particle (Fig. 12b and c). This results in precipitation of further corrosion products over the $\alpha-\mathrm{Mg}$ matrix. This process takes place repeatedly and simultaneously on every particle until the metal surface is completely covered. Essentially, this layer hinders electrolyte access to the alloy surface, thereby contributing to the corrosion protection. This, however, may be compromised by subsequent dehydration and/or internal stress relieve that would incur damage to the hydroxide layer by generating cracks and holes, restoring the corrosion rate (Fig. 12c).

Williams et al [54] used Scanning Vibrating Electrode Technique (SVET) to study the evolution of corrosion process on pure magnesium in chloride media. They also observed a modification on the electrochemical behaviour at active corrosion sites. Anodic corrosion initiation points propagated radially, leaving behind a corroded and blackened surface. These dark regions, presumably formed by corrosion products, were strongly cathodic, which is consistent with the results of SKPFM analysis presented in this work. Additionally, they observed that the corrosion rate decreased considerably when the majority of the exposed area was completely covered, changing the corrosion mechanism from localised to uniform corrosion.

The presence of chloride ions in the environment may also lead to the formation of oxychlorides containing corrosion products that appear as needle-like crystals on the corroded surface [35, 51] also found in Fig. 7:

$$
x \mathrm{Mg}^{2+}+\mathrm{Cl}^{-}+y \mathrm{OH}^{-}+z \mathrm{H}_{2} \mathrm{O} \rightarrow \mathrm{Mg}_{x}(\mathrm{OH})_{y} \mathrm{Cl} \cdot z \mathrm{H}_{2} \mathrm{O}
$$

Moreover, $\mathrm{Mg}$ and $\mathrm{Ca}$ oxychlorides can also appear on the surface as adsorbed intermediate products of aqueous corrosion process which is catalysed in presence of $\mathrm{Cl}^{-}$ions [55]:

$$
\begin{aligned}
& \mathrm{Me}+\mathrm{Cl}^{-}+\mathrm{H}_{2} \mathrm{O} \leftrightarrow\left[\mathrm{MeCl}(\mathrm{OH})^{-}\right]_{\mathrm{ads}}+\mathrm{H}^{+}+\mathrm{e}^{-} \\
& {\left[\mathrm{MeCl}(\mathrm{OH})^{-}\right]_{\mathrm{ads}} \leftrightarrow \mathrm{MeClOH}+\mathrm{e}^{-}} \\
& \mathrm{MeClOH}+\mathrm{H}^{+} \leftrightarrow \mathrm{Me}^{2+}+\mathrm{Cl}^{-}+\mathrm{H}_{2} \mathrm{O}
\end{aligned}
$$

In any case, a balance between the hydroxide precipitation and dissolution will eventually be achieved. 
4.2. Implications of $\mathrm{Mg}-\mathrm{Ca}$ alloy nanostructure on corrosion mechanism

The solubility of $\mathrm{Ca}$ in $\mathrm{Mg}$ matrix is quite low and from room temperature to $380{ }^{\circ} \mathrm{C}$, this value stays under 0.82 at $\%$; therefore, all structures in Fig. 2 contain the secondary phase $\mathrm{Mg}_{2} \mathrm{Ca}$. In the homogenised CG alloy, the secondary phase appear as stationary particles $\beta_{\mathrm{I}}-\mathrm{Mg}_{2} \mathrm{Ca}$ located along the grain boundaries (Fig 2a, b). The higher potential values of the corrosion products formed over the $\beta_{\mathrm{I}}-\mathrm{Mg}_{2} \mathrm{Ca}$ (Table 3) lead to a more severe microgalvanic corrosion following the grain boundaries, compared to that of UFG and NC alloys (Fig. 13a). Additionally, the bigger size of the stationary particles $\beta_{\mathrm{I}}-\mathrm{Mg}_{2} \mathrm{Ca}$ in the $\mathrm{CG}$ alloy promotes the precipitation of big and heterogeneous lumps of corrosion products (Fig. 7a).

The HPT process generates numerous dislocations, transforming the CG structure into NC (Fig. 2e). During this process, the secondary phase partly dissolves in the matrix, as follows from the values of the volume and mass fractions, and $\mathrm{Mg}$ cell parameters; this increases the strain in the material structure now having a supersaturated solid solution of $\mathrm{Ca}$ in $\mathrm{Mg}$ matrix (Table 2). Since the volume fraction of the stationary particles $\beta_{\mathrm{I}}-\mathrm{Mg}_{2} \mathrm{Ca}$ becomes lower, the size and density of pitting corrosion sites also decrease, reducing the overall corrosion rate; moreover, the stationary phase particles no longer form straight paths for the corrosion propagation along the grain boundaries, as in the CG alloy (Fig. 13a). As a result, smaller and more closely located $\beta_{\mathrm{I}^{-}}$ $\mathrm{Mg}_{2} \mathrm{Ca}$ particles with lower surface potential values (Table 3) observed in NC alloy, promote a rapid formation on the metal surface of a thin and homogeneous film of corrosion products with better protection properties (Fig. 13c).

After the annealing, the NC structure transforms into the UFG, which exhibits more equilibrium state of the grain boundaries, with less dislocation density and partial relaxation of internal stress (Table 2). Importantly, the supersaturated solid solution of $\mathrm{Ca}$ in $\mathrm{Mg}$ matrix partly decomposes, forming uniformly distributed $\beta_{\mathrm{II}}-\mathrm{Mg}_{2} \mathrm{Ca}$ nano-precipitates within the grain bodies (Fig 2d). Moreover, smaller amounts $\mathrm{Mg}_{2} \mathrm{Ca}$ along grain boundaries make them less susceptible to the corrosion propagation. As a result, magnesium/calcium hydroxides that appear due to corrosion on top of the secondary phase particles and nano-precipitates, protect a larger surface area compared to that of both CG and NC samples (Fig. 13b).

The cracks in the corrosion products formed on the CG substrate provide paths for the corrosion following grain boundaries, resulting in rapid sample disintegration (Fig. 5) [56]. Corrosion in UFG and NC Mg-1Ca alloys does not proceed via secondary phase paths along the grain boundaries since $\beta_{\mathrm{I}}-\mathrm{Mg}_{2} \mathrm{Ca}$ particles are separated (Fig. 2c, 2e) and eventually the surface becomes covered by thin, semi-protective corrosion product layer. The smallest potential difference is observed for the UFG alloy (Fig. 8, Table 3) due to both presence of separated 
stationary phase particles $\beta_{\mathrm{I}}-\mathrm{Mg}_{2} \mathrm{Ca}$ at the former sites of grain boundaries in the $\mathrm{CG}$ structure, and uniformly distributed $\beta_{\mathrm{II}}-\mathrm{Mg}_{2} \mathrm{Ca}$ nano-precipitates within the grain bodies (Fig. 13b). This combination provides the best corrosion protection.

4.3. Electrochemical implications and challenges in corrosion understanding for UFG and $\mathrm{NC} \mathrm{Mg-1Ca} \mathrm{alloys}$

Several authors have observed that the corrosion resistance of nanostructured magnesium alloys greatly depends on the grain size. Most of them agree that microstructures with small grain size and a high fraction of grain boundaries promote passivation $[57,58]$, which is in accordance with the corrosion mechanism proposed in this work (Fig. 12, 13). However, this is not the only factor determining the corrosion behaviour of nanostructured magnesium alloys [59]. PDP curves (Fig. 9) showed that the nanostructuring reduces $E_{c o r r}$ and shifts the cathodic branches towards lower current densities, with little influence on the anodic branch. Interestingly, the specimens with lower corrosion rates presented more anodic $E_{c o r r}$ values [60], i.e. have a more active nature. However, it is worth highlighting that the corrosion potential is a thermodynamic property of a specific metal/electrolyte system and does not provide kinetic information on the corrosion process [61]. On the contrary, the displacement of the cathodic branch suggests that the kinetics of the corrosion process in cathodically controlled. Cathodic regions that appear in the neighbourhood of the secondary phases and at the grain boundaries have a certain width represented by the width of the valleys in Fig. 4. As suggested elsewhere [38], this width does not change with the grain refinement, and gradually, the cathode area covers the whole grain; this contributes to the decrease in both the potential difference and corrosion current (Tables 2 and 4). The lower corrosion current densities of UFG compared to the NC alloy are associated with the annealing post-treatment to release residual stresses (Table 2). Op't Hoog et al observed that the cathodic kinetics increases if large residual stresses remain after grain refinement $[60,61]$. This could be related to the local decrease in the surface potential of the matrix at the vicinity of dislocations, which promotes anodic dissolution [62].

As discussed elsewhere $[25,34,35]$, the presence in the impedance spectra of two time constants with the capacitive response, and one time constant with the inductive response is reflected in the ladder type structure of the equivalent circuit (Fig. 11) [33]. The former two are attributed to the inner compact layer $\mathrm{R}_{2}-\mathrm{C}_{2}$ within the outer porous layer $\mathrm{R}_{1}-\mathrm{C}_{1}$, whereas the latter $\left(\mathrm{R}_{3}-\mathrm{L}\right)$ has no direct physical meaning, and, according to various studies, describes the corrosion product layer breakdown and damage propagation to the substrate [32, 63]. As pointed out by King et al [33], there is a potential dependency of the inductance, and its appearance is associated with 
the acceleration of the anodic dissolution; not taking into account this inductive response will result in overestimation of the corrosion resistance.

The analysis of Table 5 shows that resistance $\mathrm{R}_{1}$ standing for the porous outer layer of the corrosion products decreases with the substrate nanostructuring; this is consistent with Fig. 7. The inner layer/charge transfer resistance $\mathrm{R}_{2}$ significantly increases with the substrate nanostructuring, with the highest value corresponding to the UFG alloy. This indicates that the nanostructuring promotes the formation of a more uniform and less defect surface oxide/hydroxide layer, which is consistent with the proposed mechanism. The secondary phase anodic dissolution process generates cracks and pits that result in a significant decrease of the coating resistance for the $\mathrm{CG}$ alloy.

It is noteworthy that the resistance $\mathrm{R}_{3}$ standing for the inductive loop is positive for the CG alloy and negative for UFG and NC. Therefore, at frequencies below $0.1 \mathrm{~Hz}$, the system shows unusual behaviour for the UFG and NC alloys; this is probably due to the segregation of the secondary phase particles and further formation of nano-precipitates in the non-equilibrium alloy NC and UFG structures. Mg alloys are known to exhibit non-stationarity and data scattering at lower frequencies, and the impedance modulus usually decreases due to the induction shunting of the RC part of the equivalent circuit. In contrast, the low-frequency increase in the impedance observed in this work has significant implications for the corrosion resistance, and this is where the EIS model shows the difference between $\mathrm{CG}$ and UFG/NC samples.

The overall corrosion protection assessment can be carried out based on polarisation resistance $R_{f \rightarrow 0}$ calculated using the values of equivalent circuit elements at frequencies approaching zero, as follows [31, 33, 35]: $\mathrm{R}_{\mathrm{f} \rightarrow 0}=\left(\mathrm{R}_{3} \cdot\left(\mathrm{R}_{1}+\mathrm{R}_{2}\right)\right) /\left(\mathrm{R}_{1}+\mathrm{R}_{2}+\mathrm{R}_{3}\right)$. The values obtained and shown in Table 5 are consistent both with the polarisation resistance values $R_{p}$ (Table 4), and the corrosion behaviour observed during the immersion test. Therefore, this new unusual impedance behaviour adequately describes the increase in the corrosion resistance observed for the UFG and NC Mg-1Ca alloys.

To explain this behaviour, it can be considered that the inductance $\mathrm{L}_{1}$ represents a kinetic effect of corrosion propagation on anodic sites, which is consistent with the results obtained by King et al [33]. When the potential increases within the $10 \mathrm{mV}$ of AC perturbation during the EIS test, the current increases for longer than it should be if the system exhibited only resistive behaviour, and its maximum value is reached past the voltage maximum [34]. Then the negative sign of $\mathrm{R}_{3}$ can be interpreted as additional limitations imposed on the maximum value of current due to the hydroxide precipitation process once the frequency falls below a certain threshold level, which in this case is estimated at $0.02 \mathrm{~Hz}$. This threshold is likely to reflect the time taken for nucleation of hydroxides from dissolved metal ions, beyond which they will precipitate on the 
surface, forming relatively dense deposits on the majority of active sites associated with nanoscale inclusions of the secondary phase. Since these inclusions are isolated, the local corrosion activity on them will quickly become inhibited and further propagation of corrosion would include activation of new sites, with the resulting current density being reduced. An alternative scenario may include metastable development of localised corrosion within individual anodic sites, with the ratio of local current to the site size (I/r) fluctuating around a certain critical value [64] due to the dissolution-precipitation behaviour of corrosion products. This may explain increased scattering of impedance data in the low-frequency range, however, elaboration of quantitative models describing the unusual impedance behaviour of the nanostructured $\mathrm{Mg}-\mathrm{Ca}$ alloys would require a separate investigation.

\section{Conclusions}

The study has demonstrated that the grain refinement via high-pressure torsion nanostructuring and further annealing enhances the corrosion resistance of the new biocompatible $\mathrm{Mg}-1 \mathrm{Ca}$ alloy in Ringer's solution. The associated decrease in corrosion rate leads to the increase in sample disintegration time from $3 \ldots 4$ days to more than 30 days, enabling biodegradation of resorbable $\mathrm{Mg}$ alloy implants to be controlled throughout the bone regeneration period. The mechanism underlying the controllable biodegradation is based on the balance between processes of anodic dissolution of Ca-containing secondary phase in local galvanic corrosion cells and precipitation of hydroxide compounds that contribute towards corrosion inhibition on active sites. This balance is strongly influenced by the size and distribution of the secondary phase $\mathrm{Mg}_{2} \mathrm{Ca}$ as stationary particles and nano-precipitates.

It was also found that, for the UFG and NC alloys, the impedance of the corrosion process exhibits an unusual behaviour described by a low-frequency inductive loop with a negative time constant. This loop, reflecting significant increases in the impedance modulus at frequencies below $0.1 \mathrm{~Hz}$, is likely to originate from a metastable progression of corrosion process on the secondary phases, affected by dissolution-precipitation behaviour of corrosion products. Such kinetic effect explains particularly low corrosion rates observed on these alloys during the immersion test. Among the studied materials, the best corrosion resistance was provided by the UFG Mg-1Ca alloy with a grain size of 0.9 to $1.3 \mu \mathrm{m}$, exhibiting $\mathrm{Mg}_{2} \mathrm{Ca}$ nano-precipitates formed within the magnesium matrix as a consequence of the annealing. This, together with the high ultimate strength, ductility and low internal stress of the alloy, makes it a promising candidate for future biodegradable $\mathrm{Mg}$ implants. 


\section{Acknowledgements}

This work was supported by the Ministry of Education and Science of the Russian Federation through a platform grant in the field of basic research (No. 16.7268.2017/8.9). V.R.M. acknowledges support from the Russian Foundation of Basic Research, grant No. 16-38-60062 for young scientists. A.Y. acknowledges support from ERC Advanced Grant (\#320879‘IMPUNEP’). B.M. is grateful to The University of Manchester for the award of the Presidential Fellowship. R.Z.V. and E.V.P. acknowledge support from the Russian Science Foundation, grant No. 19-4902003. The authors also thank Nanotech Centre at Ufa State Aviation Technical University and Research Centre at the Institute of Petroleum Refining and Petrochemistry of the Republic of Bashkortostan for surface characterisation.

\section{Data Availability}

The raw and processed data required to reproduce these findings are available to download from http://dx.doi.org/10.17632/ccrp8sc3sj.1. Some data cannot be shared at this time as the data also forms a part of an ongoing study.

\section{References}

[1] H. Li, Y. Zheng, L. Qin, Progress of biodegradable metals, Prog. Nat. Sci., 24 (2014) 414-422.

[2] N.B. Pilling, R.E. Bedworth, The Oxidation of Metals at High Temperatures, J. Inst. Met., 29 (1923) 529-591.

[3] Y.F. Zheng, X.N. Gu, F. Witte, Biodegradable metals, Mater Sci Eng R Rep, 77 (2014) $1-34$.

[4] R.-C. Zeng, L. Sun, Y.-F. Zheng, H.-Z. Cui, E.-H. Han, Corrosion and characterisation of dual phase $\mathrm{Mg}-\mathrm{Li}-\mathrm{Ca}$ alloy in Hank's solution: The influence of microstructural features, Corrosion Science, 79 (2014) 69-82.

[5] L.-Y. Cui, X.-T. Li, R.-C. Zeng, S.-Q. Li, E.-H. Han, L. Song, In vitro corrosion of Mg-Ca alloy — The influence of glucose content, Front. Mater. Sci., 11 (2017) 284-295.

[6] H.R.B. Rad, M.H. Idris, M.R.A. Kadir, S. Farahany, Microstructure analysis and corrosion behavior of biodegradable Mg-Ca implant alloys, Materials \& Design, 33 (2012) 88-97.

[7] W. Xu, N. Birbilis, G. Sha, Y. Wang, J.E. Daniels, Y. Xiao, M. Ferry, A high-specificstrength and corrosion-resistant magnesium alloy, Nat. Mater., 14 (2015) 1229-1235.

[8] T.C. Lowe, R.Z. Valiev, Frontiers for Bulk Nanostructured Metals in Biomedical Applications, in: Advanced Biomaterials and Biodevices, Wiley Blackwell, 2014, pp. 1-52. 
[9] R.Z. Valiev, A.P. Zhilyaev, T.G. Langdon, Bulk nanostructured materials: Fundamentals and applications, Wiley, 2013.

[10] Y. Huang, T.G. Langdon, Advances in ultrafine-grained materials, Materials Today, 16 (2013) 85-93.

[11] L. Mishnaevsky, E. Levashov, R.Z. Valiev, J. Segurado, I. Sabirov, N. Enikeev, S. Prokoshkin, A.V. Solov’yov, A. Korotitskiy, E. Gutmanas, I. Gotman, E. Rabkin, S. Psakh’e, L. Dluhoš, M. Seefeldt, A. Smolin, Nanostructured titanium-based materials for medical implants: Modeling and development, Materials Science and Engineering: R: Reports, 81 (2014) 1-19.

[12] J.W. Seong, W.J. Kim, Mg-Ca binary alloy sheets with Ca contents of $\leq 1 \mathrm{wt} . \%$ with high corrosion resistance and high toughness, Corrosion Science, 98 (2015) 372-381.

[13] Z. Li, X. Gu, S. Lou, Y. Zheng, The development of binary Mg-Ca alloys for use as biodegradable materials within bone, Biomaterials, 29 (2008) 1329-1344.

[14] R.Z. Valiev, R.K. Islamgaliev, I.V. Alexandrov, Bulk nanostructured materials from severe plastic deformation, Progress in Materials Science, 45 (2000) 103-189.

[15] O.B. Kulyasova, R.K. Islamgaliev, Y. Zhao, R.Z. Valiev, Enhancement of the Mechanical Properties of an Mg-Zn-Ca Alloy Using High-Pressure Torsion, Advanced Engineering Materials, 17 (2015) 1738-1741.

[16] O.B. Kulyasova, R.K. Islamgaliev, R.Z. Valiev, Microstructure and mechanical properties of ultrafine-grained Mg-Zn-Ca alloy, Defect Diffus. Forum, 381 DDF (2017) 39-43.

[17] X. Li, X. Liu, S. Wu, K.W. Yeung, Y. Zheng, P.K. Chu, Design of magnesium alloys with controllable degradation for biomedical implants: From bulk to surface, Acta biomaterialia, 45 (2016) 2-30.

[18] O.B. Kulyasova, R.K. Islamgaliev, E.V. Parfenov, Y.F. Zheng, R.Z. Valiev, Microstructure, mechanical and corrosion properties of ultrafine-grained $\mathrm{Mg}$ - $2 \% \mathrm{Sr}$ alloy, in: 2018 6th International Conference on Nanomaterials and Materials Engineering, ICNME 2018, Institute of Physics Publishing, 2018.

[19] F. Cao, Z. Shi, G.-L. Song, M. Liu, A. Atrens, Corrosion behaviour in salt spray and in $3.5 \% \mathrm{NaCl}$ solution saturated with $\mathrm{Mg}(\mathrm{OH}) 2$ of as-cast and solution heat-treated binary $\mathrm{Mg}-\mathrm{X}$ alloys: X=Mn, Sn, Ca, Zn, Al, Zr, Si, Sr, Corrosion Science, 76 (2013) 60-97.

[20] K. Gusieva, C. Davies, J. Scully, N. Birbilis, Corrosion of magnesium alloys: the role of alloying, Int. Mater. Rev., 60 (2015) 169-194.

[21] W.-C. Kim, J.-G. Kim, J.-Y. Lee, H.-K. Seok, Influence of Ca on the corrosion properties of magnesium for biomaterials, Mater Lett, 62 (2008) 4146-4148.

[22] Y. Jin, C. Blawert, F. Feyerabend, J. Bohlen, M. Silva Campos, S. Gavras, B. Wiese, D. Mei, M. Deng, H. Yang, R. Willumeit-Römer, Time-sequential corrosion behaviour 
observation of micro-alloyed $\mathrm{Mg}-0.5 \mathrm{Zn}-0.2 \mathrm{Ca}$ alloy via a quasi-in situ approach, Corrosion Science, (2019) 108096.

[23] E.K. Brooks, M.T. Ehrensberger, Bio-Corrosion of Magnesium Alloys for Orthopaedic Applications, J Funct Biomater, 8 (2017) 38.

[24] R. Zeng, W. Qi, F. Zhang, H. Cui, Y. Zheng, In vitro corrosion of Mg-1.21Li1.12Ca-1Y alloy, Prog. Nat. Sci., 24 (2014) 492-499.

[25] M. Mohedano, B.J.C. Luthringer, B. Mingo, F. Feyerabend, R. Arrabal, P.J. Sanchez-Egido, C. Blawert, R. Willumeit-Römer, M.L. Zheludkevich, E. Matykina, Bioactive plasma electrolytic oxidation coatings on $\mathrm{Mg}-\mathrm{Ca}$ alloy to control degradation behaviour, Surface and Coatings Technology, 315 (2017) 454-467.

[26] R.-C. Zeng, W.-C. Qi, H.-Z. Cui, F. Zhang, S.-Q. Li, E.-H. Han, In vitro corrosion of as-extruded $\mathrm{Mg}-\mathrm{Ca}$ alloys-The influence of Ca concentration, Corrosion Science, 96 (2015) 23-31.

[27] M. Bornapour, M. Celikin, M. Cerruti, M. Pekguleryuz, Magnesium implant alloy with low levels of strontium and calcium: The third element effect and phase selection improve bio-corrosion resistance and mechanical performance, Materials Science and Engineering: C, 35 (2014) 267-282.

[28] Y. Wan, G. Xiong, H. Luo, F. He, Y. Huang, X. Zhou, Preparation and characterization of a new biomedical magnesium-calcium alloy, Materials \& Design, 29 (2008) 2034-2037.

[29] O.I. Velikokhatnyi, P.N. Kumta, First-principles studies on alloying and simplified thermodynamic aqueous chemical stability of calcium-, zinc-, aluminum-, yttrium- and iron-doped magnesium alloys, Acta biomaterialia, 6 (2010) 1698-1704.

[30] Z. Li, X. Gu, S. Lou, Y. Zheng, The development of binary Mg-Ca alloys for use as biodegradable materials within bone, Biomaterials, 29 (2008) 1329-1344.

[31] M. Esmaily, J.E. Svensson, S. Fajardo, N. Birbilis, G.S. Frankel, S. Virtanen, R. Arrabal, S. Thomas, L.G. Johansson, Fundamentals and advances in magnesium alloy corrosion, Progress in Materials Science, 89 (2017) 92-193.

[32] G.-L. Song, Z. Shi, Corrosion mechanism and evaluation of anodized magnesium alloys, Corrosion Science, 85 (2014) 126-140.

[33] A.D. King, N. Birbilis, J.R. Scully, Accurate Electrochemical Measurement of Magnesium Corrosion Rates; a Combined Impedance, Mass-Loss and Hydrogen Collection Study, Electrochim Acta, 121 (2014) 394-406. 
[34] M. Curioni, F. Scenini, T. Monetta, F. Bellucci, Correlation between electrochemical impedance measurements and corrosion rate of magnesium investigated by real-time hydrogen measurement and optical imaging, Electrochim Acta, 166 (2015) 372-384.

[35] Y. Gao, A. Yerokhin, E. Parfenov, A. Matthews, Application of Voltage Pulse Transient Analysis during Plasma Electrolytic Oxidation for Assessment of Characteristics and Corrosion Behaviour of Ca- and P-containing Coatings on Magnesium, Electrochim Acta, 149 (2014) 218-230.

[36] A.D. Südholz, N.T. Kirkland, R.G. Buchheit, N. Birbilis, Electrochemical properties of intermetallic phases and common impurity elements in magnesium alloys, Electrochem Solid State Letters, 14 (2011) C5-C7.

[37] R.C. Zeng, J. Zhang, W.J. Huang, W. Dietzel, K.U. Kainer, C. Blawert, W. Ke, Review of studies on corrosion of magnesium alloys, Transactions of Nonferrous Metals Society of China (English Edition), 16 (2006) s763-s771.

[38] H. Miyamoto, Corrosion of Ultrafine Grained Materials by Severe Plastic Deformation, an Overview, Materials Transactions, 57 (2016) 559-572.

[39] K.D. Ralston, N. Birbilis, Effect of Grain Size on Corrosion: A Review, Corrosion, 66 (2010) 075005-075005-075013.

[40] G.K. Williamson, W.H. Hall, X-ray line broadening from filed aluminium and wolfram, Acta Metallurgica, 1 (1953) 22-31.

[41] R.A. Young, The Rietveld method, International Union of Crystallography ; Oxford University Press, Chester, England; Oxford ; New York, 1993.

[42] S. Grazulis, D. Chateigner, R.T. Downs, A.F. Yokochi, M. Quiros, L. Lutterotti, E. Manakova, J. Butkus, P. Moeck, A. Le Bail, Crystallography Open Database - an open-access collection of crystal structures, J Appl Crystallogr, 42 (2009) 726-729.

[43] K.A. Yasakau, I. Giner, C. Vree, O. Ozcan, R. Grothe, A. Oliveira, G. Grundmeier, M.G.S. Ferreira, M.L. Zheludkevich, Influence of stripping and cooling atmospheres on surface properties and corrosion of zinc galvanizing coatings, Applied Surface Science, 389 (2016) 144156.

[44] E. Barsukov, J.R. Macdonald, Impedance Spectroscopy: Theory, Experiment, and Applications, 2nd ed., John Willey \& Sons, Inc, Hoboken, 2005.

[45] B.A. Boukamp, A Linear Kronig-Kramers Transform Test for Immittance Data Validation, J Electrochem Soc, 142 (1995) 1885-1901.

[46] J.R. Scully, Polarization resistance method for determination of instantaneous corrosion rates, Corrosion, 56 (2000) 199-217. 
[47] S. Koleini, M.H. Idris, H. Jafari, Influence of hot rolling parameters on microstructure and biodegradability of $\mathrm{Mg}-1 \mathrm{Ca}$ alloy in simulated body fluid, Materials \& Design, 33 (2012) 20-25.

[48] N. Li, Y.D. Li, Y.X. Li, Y.H. Wu, Y.F. Zheng, Y. Han, Effect of surface mechanical attrition treatment on biodegradable $\mathrm{Mg}-1 \mathrm{Ca}$ alloy, Materials science \& engineering. C, Materials for biological applications, 35 (2014) 314-321.

[49] A. Bahmani, S. Arthanari, K.S. Shin, Corrosion behavior of $\mathrm{Mg}-\mathrm{Mn}-\mathrm{Ca}$ alloy: Influences of Al, Sn and Zn, Journal of Magnesium and Alloys, 7 (2019) 38-46.

[50] Z.-Y. Ding, L.-Y. Cui, R.-C. Zeng, Y.-B. Zhao, S.-K. Guan, D.-K. Xu, C.-G. Lin, Exfoliation corrosion of extruded Mg-Li-Ca alloy, Journal of Materials Science \& Technology, 34 (2018) 1550-1557.

[51] M. Sun, A. Yerokhin, M.Y. Bychkova, D.V. Shtansky, E.A. Levashov, A. Matthews, Self-healing plasma electrolytic oxidation coatings doped with benzotriazole loaded halloysite nanotubes on AM50 magnesium alloy, Corrosion Science, 111 (2016) 753-769.

[52] M.M. Avedesian, H. Baker, ASM International. Handbook Committee., Magnesium and magnesium alloys, ASM International, Materials Park, OH, 1999.

[53] J.A. Dean, N.A. Lange, Lange's handbook of chemistry, in, McGraw-Hill, New York, 1999, pp. 1561.

[54] G. Williams, H.N. McMurray, R. Grace, Inhibition of magnesium localised corrosion in chloride containing electrolyte, Electrochimica Acta, 55 (2010) 7824-7833.

[55] Y. Zhu, M.L. Free, R. Woollam, W. Durnie, A review of surfactants as corrosion inhibitors and associated modeling, Progress in Materials Science, 90 (2017) 159-223.

[56] Y.S. Jeong, W.J. Kim, Enhancement of mechanical properties and corrosion resistance of $\mathrm{Mg}-\mathrm{Ca}$ alloys through microstructural refinement by indirect extrusion, Corrosion Science, 82 (2014) 392-403.

[57] G.R. Argade, S.K. Panigrahi, R.S. Mishra, Effects of grain size on the corrosion resistance of wrought magnesium alloys containing neodymium, Corrosion Science, 58 (2012) 145-151.

[58] C. Liu, H. Zheng, X. Gu, B. Jiang, J. Liang, Effect of severe shot peening on corrosion behavior of AZ31 and AZ91 magnesium alloys, Journal of Alloys and Compounds, 770 (2019) 500-506.

[59] K. Ralston, N. Birbilis, Effect of grain size on corrosion: a review, Corrosion, 66 (2010) 075005-075005-075013.

[60] C. op't Hoog, N. Birbilis, Y. Estrin, Corrosion of pure Mg as a function of grain size and processing route, Advanced Engineering Materials, 10 (2008) 579-582. 
[61] N. Birbilis, M.X. Zhang, Y. Estrin, Surface grain size effects on the corrosion of magnesium, in: Key Engineering Materials, Trans Tech Publ, 2008, pp. 229-240.

[62] G.B. Hamu, D. Eliezer, L. Wagner, The relation between severe plastic deformation microstructure and corrosion behavior of AZ31 magnesium alloy, Journal of Alloys and Compounds, 468 (2009) 222-229.

[63] Z.-Y. Ding, L.-Y. Cui, X.-B. Chen, R.-C. Zeng, S.-K. Guan, S.-Q. Li, F. Zhang, Y.H. Zou, Q.-Y. Liu, In vitro corrosion of micro-arc oxidation coating on Mg-1Li-1Ca alloy — The influence of intermetallic compound Mg2Ca, Journal of Alloys and Compounds, 764 (2018) 250260.

[64] J. Soltis, Passivity breakdown, pit initiation and propagation of pits in metallic materials - Review, Corrosion Science, 90 (2015) 5-22. 
Table 1. Elemental content from the EDS within characteristic phases in CG Mg-1Ca alloy

Table 2. Grain size, $\mathrm{Mg}_{2} \mathrm{Ca}$ volume fraction from image analysis and weight fraction from Rietveld analysis, Mg matrix cell parameters and microstrain from XRD, for Mg-1Ca alloy with different structure

Table 3. Potential difference between the secondary phase $\mathrm{Mg}_{2} \mathrm{Ca}$ and the matrix in the $\mathrm{Mg}-1 \mathrm{Ca}$ alloy with different structure, before and after $24 \mathrm{~h}$ of the corrosion test

Table 4. Electrochemical corrosion characteristics of $\mathrm{Mg}-1 \mathrm{Ca}$ samples with different structure after $24 \mathrm{~h}$ of the corrosion test

Table 5. Equivalent circuit fitting results for electrochemical impedance spectroscopy of $\mathrm{Mg}-1 \mathrm{Ca}$ alloy with different structure

Table 6. Solubility products for $\mathrm{Mg}$ and Ca hydroxides [53] 


\section{List of figure captions}

Fig. 1. Treatment routine for the grain size refinement

Fig. 2. Structure of CG (a, b), UFG (c, d) and NC (e, f) Mg-1Ca alloy assessed by scanning (a, b, $\mathrm{c}, \mathrm{e})$ and transmission electron microscopy $(\mathrm{d}, \mathrm{f})$

Fig. 3. XRD spectra for Mg-1Ca alloy with CG, UFG and NC structures

Fig. 4. Surface potential maps and profiles for Mg-1Ca alloy with (a-b) CG, (c-d) UFG and (e-f) $\mathrm{NC}$ structures

Fig. 5. Appearance of $\mathrm{Mg}-1 \mathrm{Ca}$ alloy samples with $\mathrm{CG}$, UFG and $\mathrm{NC}$ structure during immersion corrosion test in Ringer's solution

Fig. 6. Weight change of Mg-1Ca alloy samples with CG, UFG and NC structure during immersion corrosion test in Ringer's solution

Fig. 7. Top view of samples with corrosion damage after $24 \mathrm{~h}$ of the immersion corrosion test in Ringer's solution: CG (a), UFG (b), NC (c)

Fig. 8. Surface potential maps and profiles for $\mathrm{Mg}-1 \mathrm{Ca}$ alloy with (a-b) CG, (c-d) UFG and (e-f) $\mathrm{NC}$ structures after $24 \mathrm{~h}$ of the corrosion test

Fig. 9. Potentiodynamic polarisation curves for the $\mathrm{Mg}-1 \mathrm{Ca}$ alloy samples with $\mathrm{CG}, \mathrm{UFG}$ and $\mathrm{NC}$ structure after $24 \mathrm{~h}$ of the immersion corrosion test in Ringer's solution

Fig. 10. EIS complex and Bode plots for $\mathrm{Mg}-1 \mathrm{Ca}$ alloy samples after $24 \mathrm{~h}$ of the immersion corrosion test in Ringer's solution

Fig. 11. Equivalent circuit for the EIS fitting

Fig. 12. Corrosion mechanism showing steps: secondary phase anodic dissolution (a), hydroxide precipitation (b) and corrosion propagation (c) for $\mathrm{Mg}-1 \mathrm{Ca}$ alloy immersed into Ringer's solution

Fig. 13. Microstructure effect on corrosion mechanism for CG (a), UFG (b) and NC (c) Mg-1Ca alloy immersed into Ringer's solution 
Table 1.

\begin{tabular}{|c|c|c|}
\hline & Mg (wt. \%) & $\mathrm{Ca}$ (wt. \%) \\
\hline Point 1 & $99.6 \pm 0.2$ & $0.4 \pm 0.2$ \\
\hline Point 2 & $96.1 \pm 0.1$ & $3.9 \pm 0.1$ \\
\hline
\end{tabular}

Table 2.

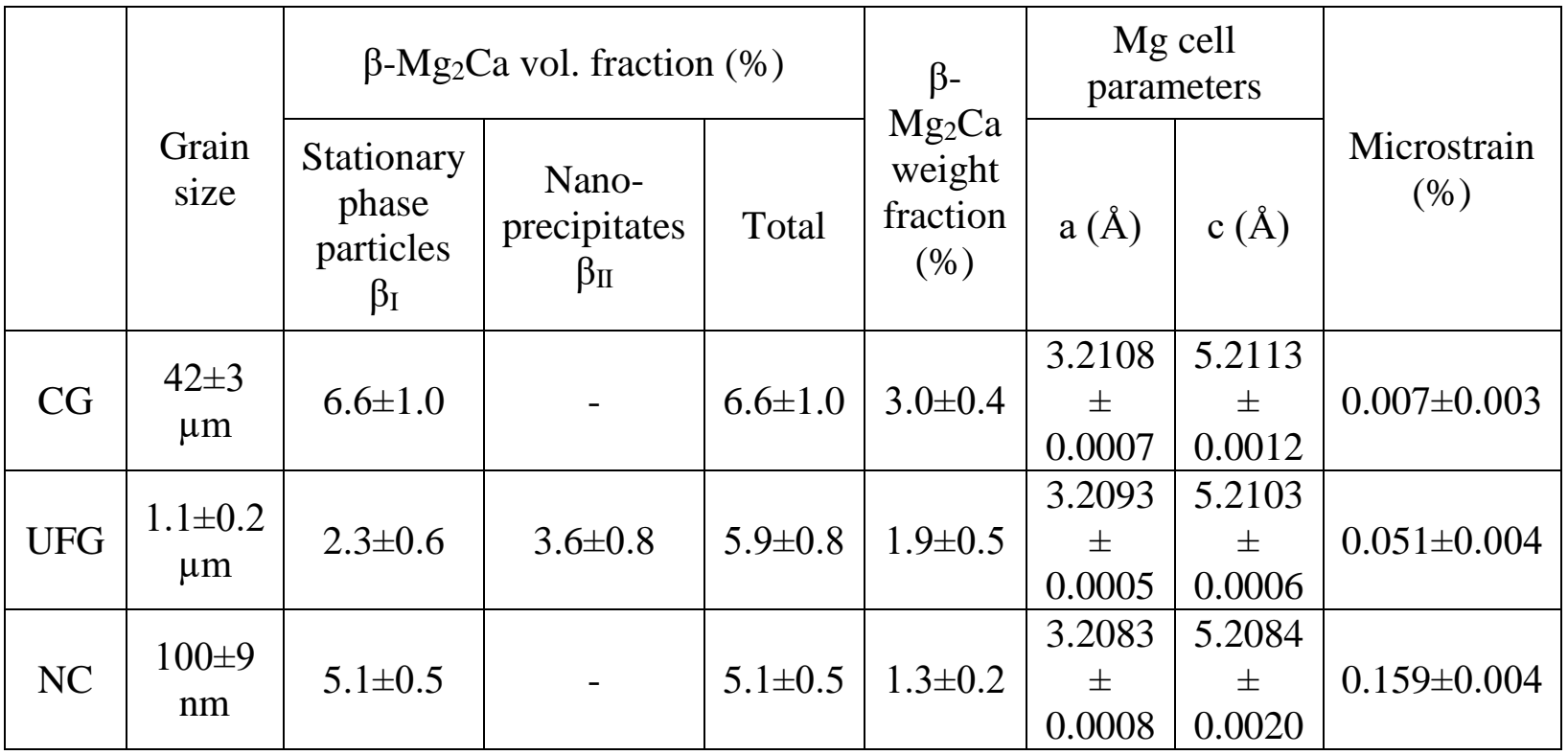

Table 3.

\begin{tabular}{|c|c|c|c|c|}
\hline \multirow{2}{*}{$\begin{array}{c}\Delta \mathrm{V} \beta-\mathrm{Mg}_{2} \mathrm{Ca} \text { to } \\
\alpha-\mathrm{Mg}(\mathrm{mV})\end{array}$} & \multicolumn{2}{|c|}{$\begin{array}{c}\text { Before } \\
\text { corrosion test }\end{array}$} & \multicolumn{2}{c|}{$\begin{array}{c}\text { After } \\
\text { corrosion test }\end{array}$} \\
\cline { 2 - 5 } & Range & Average & 75 to 400 & 238 \\
\hline $\mathrm{CG}$ & -52 to -98 & -75 & 75 to 135 & 105 \\
\hline $\mathrm{UFG}$ & -32 to -72 & -52 & 75 to 240 & 158 \\
\hline $\mathrm{NC}$ & -53 to -89 & -71 & & \\
\hline
\end{tabular}


Table 4.

\begin{tabular}{|c|c|c|c|c|}
\hline & $\begin{array}{c}E_{\text {corr }} \\
(\mathrm{V} \text { vs. AgCl })\end{array}$ & $\beta_{c}\left(\mathrm{~V} \mathrm{dec}^{-1}\right)$ & $i_{\text {corr }}\left(\mu \mathrm{A} \mathrm{cm}^{-2}\right)$ & $R_{p}\left(\Omega \mathrm{cm}^{2}\right)$ \\
\hline $\mathrm{CG}$ & $-1.463 \pm 0.005$ & $0.247 \pm 0.022$ & $53.3 \pm 26.3$ & $455 \pm 60$ \\
\hline $\mathrm{UFG}$ & $-1.512 \pm 0.019$ & $0.193 \pm 0.008$ & $3.1 \pm 0.4$ & $6963 \pm 953$ \\
\hline $\mathrm{NC}$ & $-1.475 \pm 0.032$ & $0.218 \pm 0.003$ & $4.8 \pm 1.3$ & $3238 \pm 487$ \\
\hline
\end{tabular}

Table 5.

\begin{tabular}{|c|c|c|c|c|c|c|c|c|}
\hline & $\begin{array}{c}\mathrm{R}_{\mathrm{s}} \\
\left(\Omega \mathrm{cm}^{2}\right)\end{array}$ & $\begin{array}{c}\mathrm{R}_{1} \\
\left(\Omega \mathrm{cm}^{2}\right)\end{array}$ & $\begin{array}{c}\mathrm{C}_{1} \\
\left(\mu \mathrm{F} \mathrm{cm} \mathrm{cm}^{-2}\right)\end{array}$ & $\begin{array}{c}\mathrm{R}_{2} \\
\left(\Omega \mathrm{cm}^{2}\right)\end{array}$ & $\begin{array}{c}\mathrm{C}_{2} \\
\left(\mu \mathrm{F} \mathrm{cm}^{-2}\right)\end{array}$ & $\begin{array}{c}\mathrm{R}_{3} \\
\left(\Omega \mathrm{cm}^{2}\right)\end{array}$ & $\begin{array}{c}\mathrm{L}_{1} \\
\left(\mathrm{H} \mathrm{cm}^{2}\right)\end{array}$ & $\begin{array}{c}\mathrm{R}_{\mathrm{f} \rightarrow 0} \\
(\Omega \\
\left.\mathrm{cm}^{2}\right)\end{array}$ \\
\cline { 1 - 7 } $\mathrm{CG}$ & & $87.4 \pm 6.9$ & $8.65 \pm 0.41$ & $236 \pm 7$ & $18.9 \pm 1.2$ & $982 \pm 120$ & $\begin{array}{c}17645 \\
\pm 2707\end{array}$ & 282 \\
\cline { 4 - 9 } & \multirow{2}{*}{$39.2 \pm 7.6$} & $55.5 \pm 8.0$ & $7.08 \pm 0.6$ & $662 \pm 15$ & $11.3 \pm 0.7$ & $-\mathbf{1 2 7 6} \pm 13$ & $\begin{array}{c}8204 \\
\pm 215\end{array}$ & 1679 \\
\cline { 3 - 8 } $\mathrm{NC}$ & & $36.6 \pm 1.5$ & $9.09 \pm 0.3$ & $427 \pm 3$ & $22.2 \pm 0.4$ & $-\mathbf{7 6 2} \pm 12$ & $\begin{array}{c}6946 \\
\pm 263\end{array}$ & 1223 \\
\hline
\end{tabular}

Table 6.

\begin{tabular}{|l|l|}
\hline Compound & \multicolumn{1}{|c|}{ Solubility product $\mathrm{pK}_{\mathrm{sp}}$} \\
\hline $\mathrm{Ca}(\mathrm{OH})_{2}$ & 5.26 \\
\hline $\mathrm{Mg}(\mathrm{OH})_{2}$ & 11.25 \\
\hline
\end{tabular}




\begin{tabular}{|c|c|c|c|c|c|c|}
\hline & Homogenizi & & & & & \\
\hline $\begin{array}{l}\text { As supplied } \\
\text { Mg-1Ca alloy }\end{array}$ & $\begin{array}{c}\text { heat treatment } \\
450 \pm 5^{\circ} \mathrm{C}, 12 \text { hours }\end{array}$ & $\begin{array}{l}\text { Coarse } \\
\text { grained } \\
\text { (CG) } \\
\text { samples }\end{array}$ & $\begin{array}{l}6 \mathrm{GPa}, \\
10 \text { revolutions }\end{array}$ & $\begin{array}{l}\text { Nano- } \\
\text { crystalline } \\
\text { (NC) } \\
\text { samples }\end{array}$ & $\begin{array}{c}\text { Annealing } \\
250 \pm 5^{\circ} \mathrm{C}, 6 \text { hours }\end{array}$ & $\begin{array}{l}\text { Ultrafine } \\
\text { grained } \\
\text { (UFG) } \\
\text { samples }\end{array}$ \\
\hline
\end{tabular}

Fig. 1. 

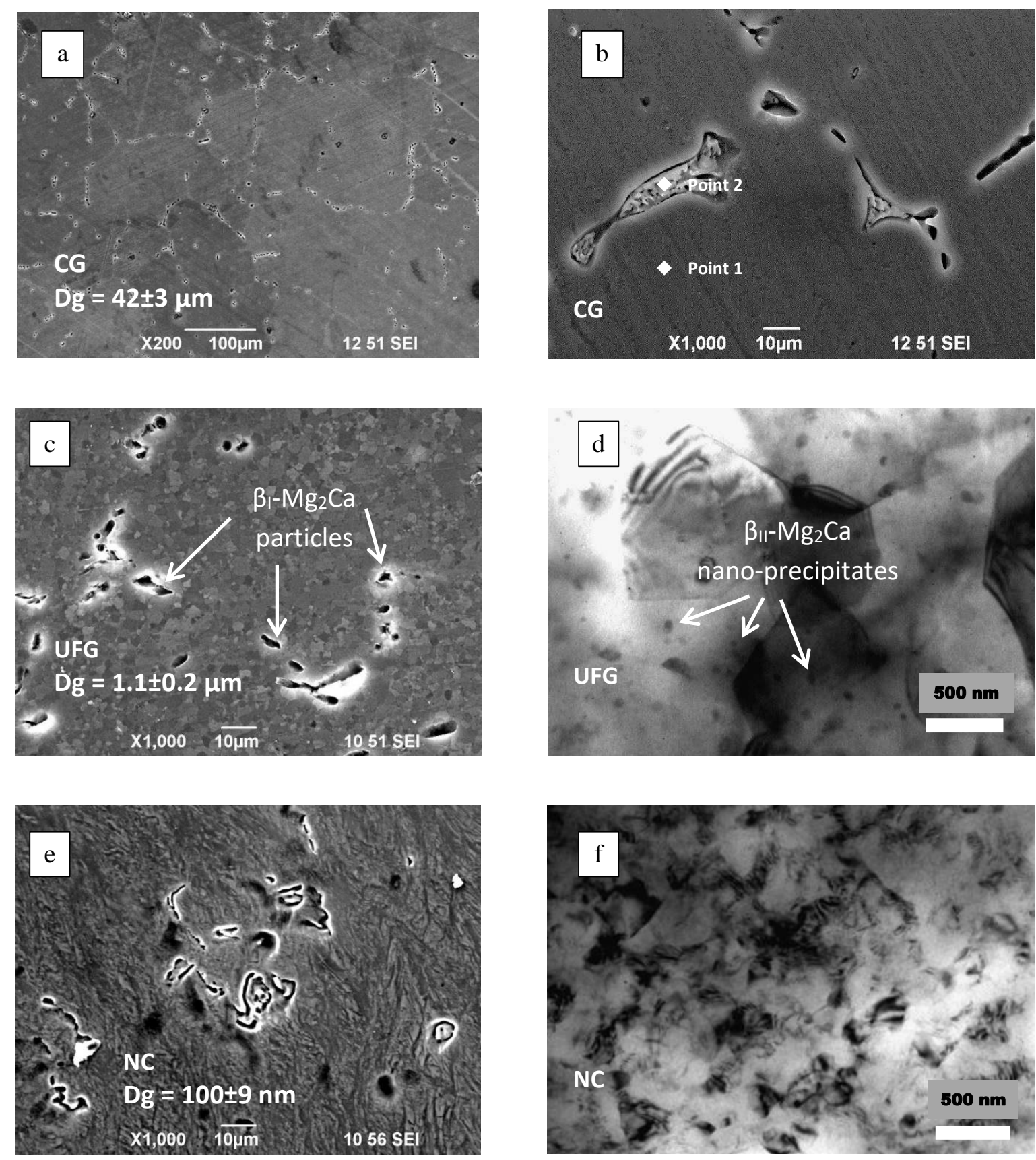

Fig. 2. 


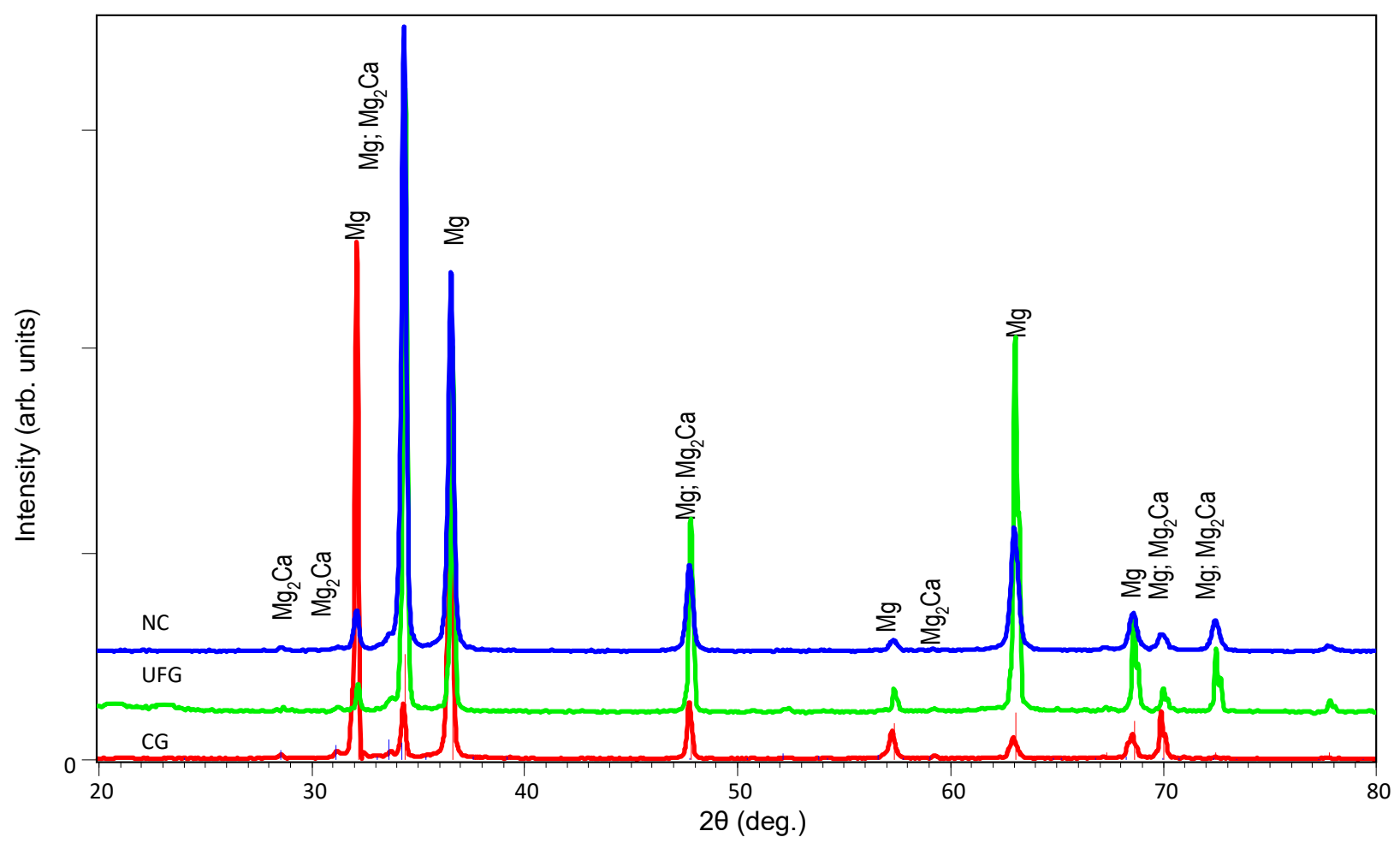

Fig. 3. 
$\mathrm{a}$

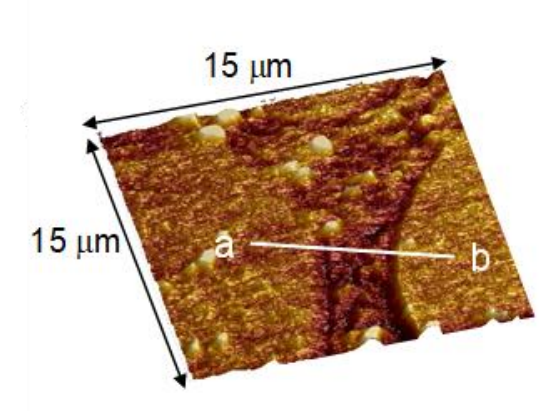

c

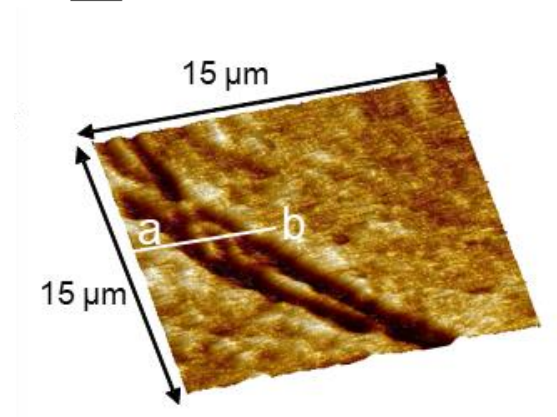

e

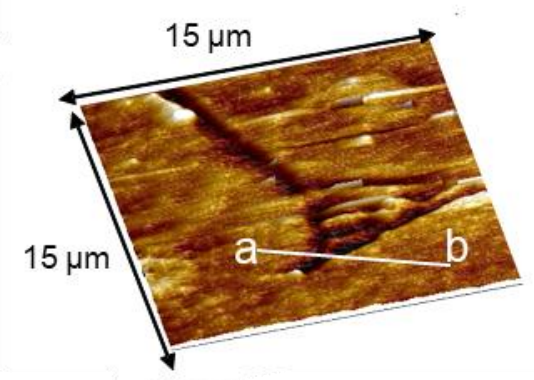

$\mathrm{b}$

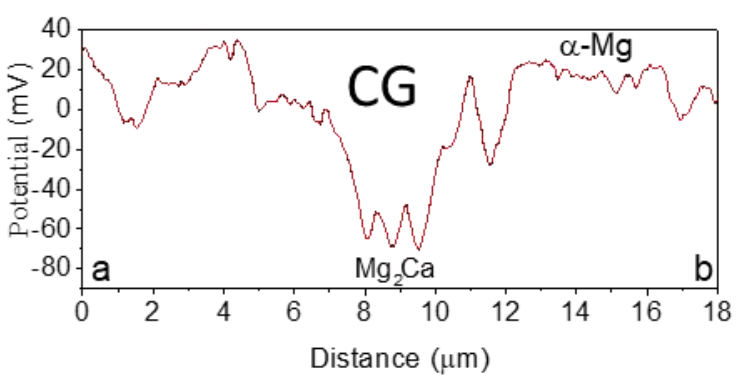

d

$60.6 \mathrm{mV}$

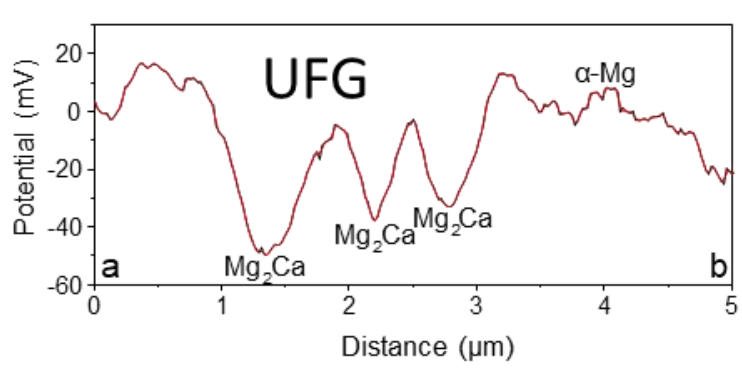

f

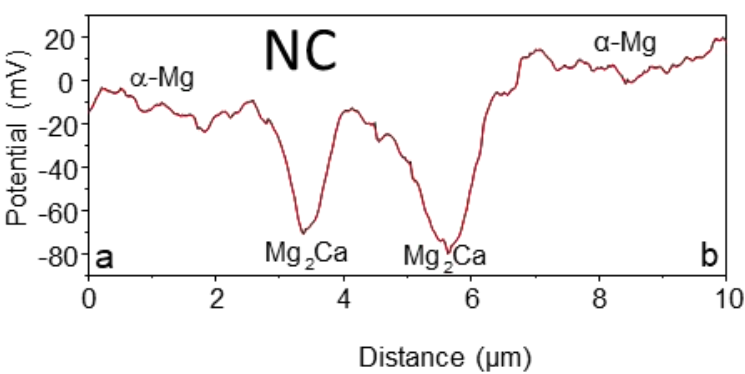

Fig. 4. 


\begin{tabular}{|c|c|c|c|c|c|c|c|}
\hline & 1 day & 4 days & 7 days & 14 days & 20 days & 28 days & 32 days \\
\hline CG & & & & & & & \\
\end{tabular}

Fig. 5. 


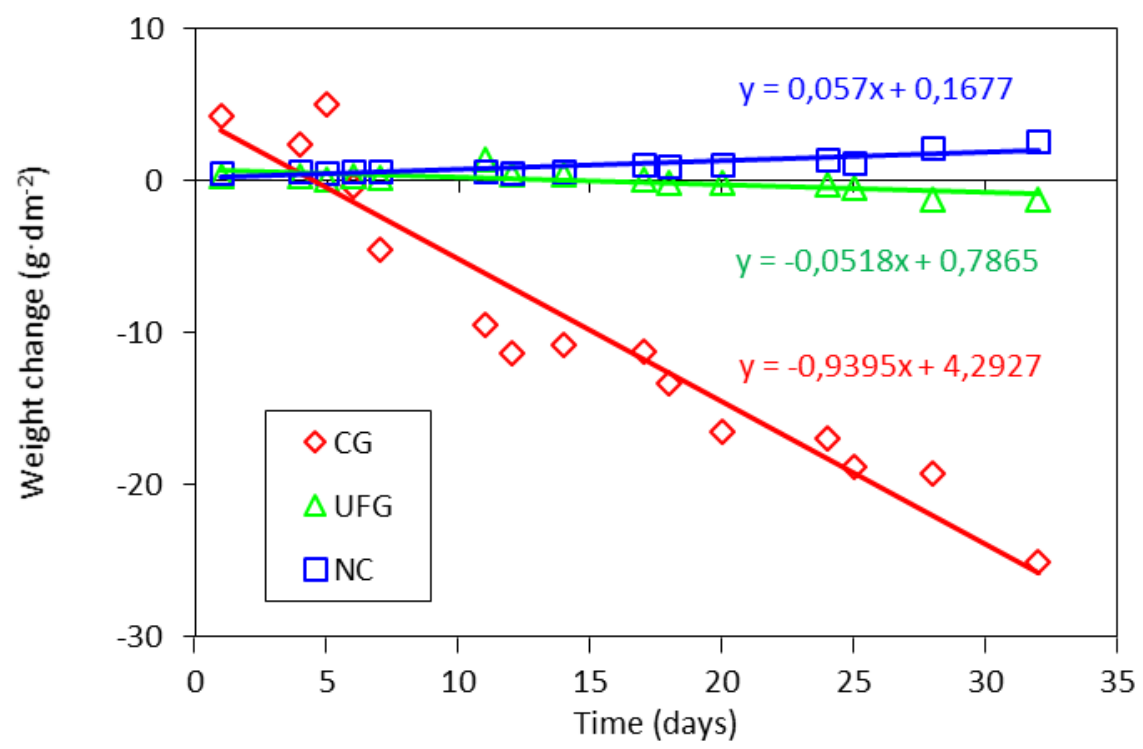

Fig. 6. 

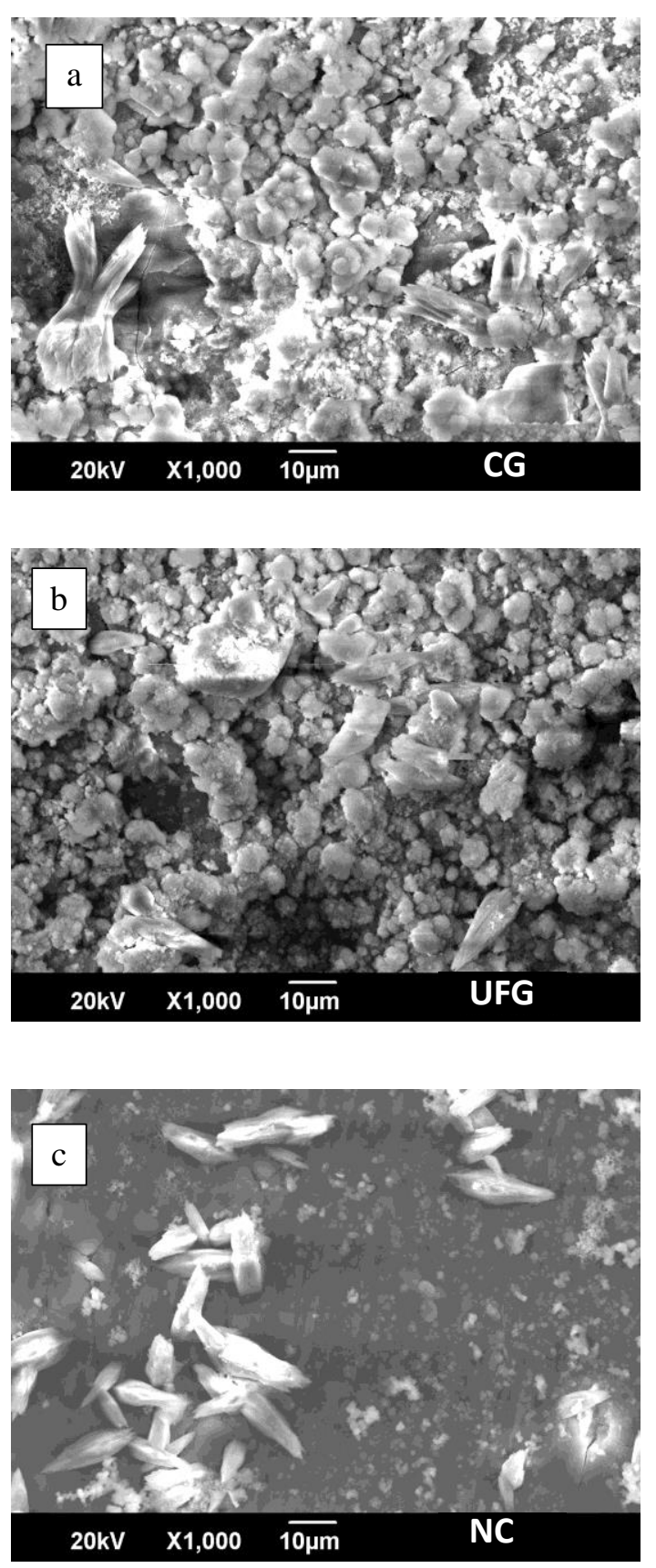

Fig. 7. 
$\mathrm{a}$

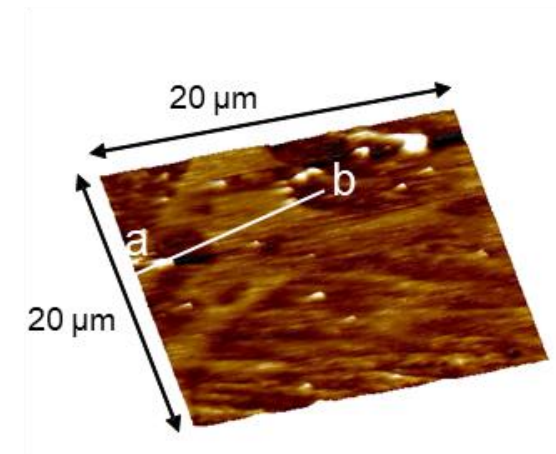

$314.3 \mathrm{mV}$

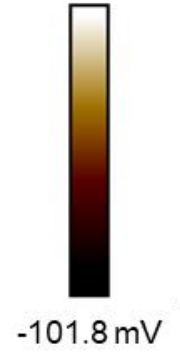

\section{c}

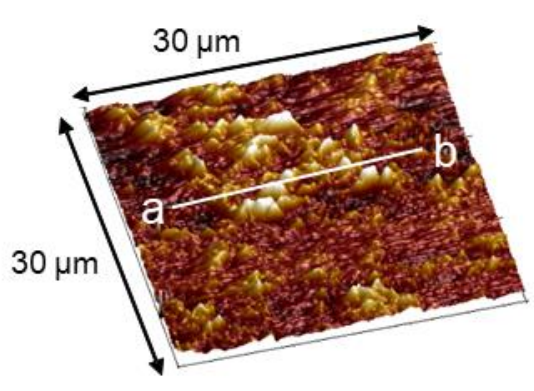

$\mathrm{e}$

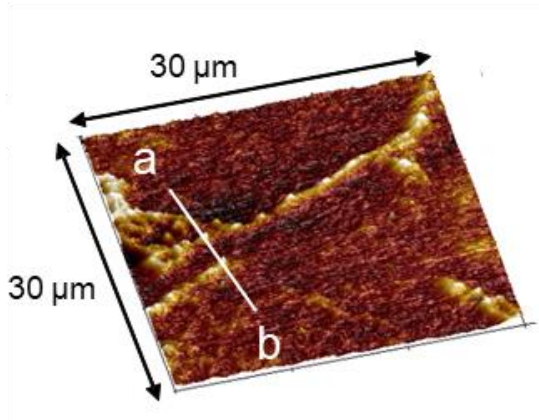

$148.6 \mathrm{mV}$ $\mathrm{b}$

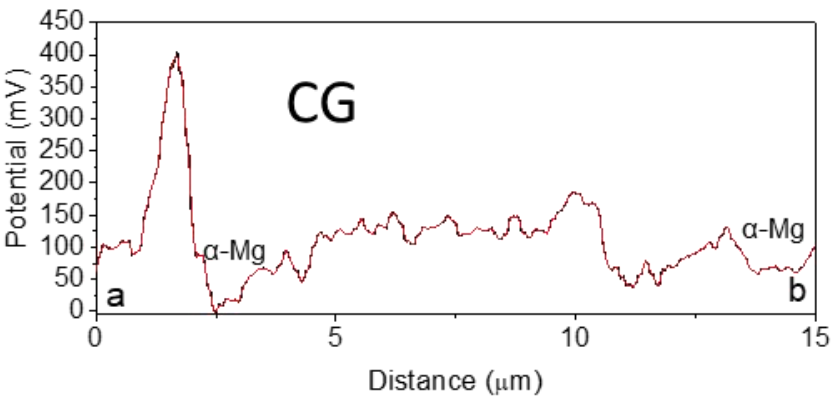

d
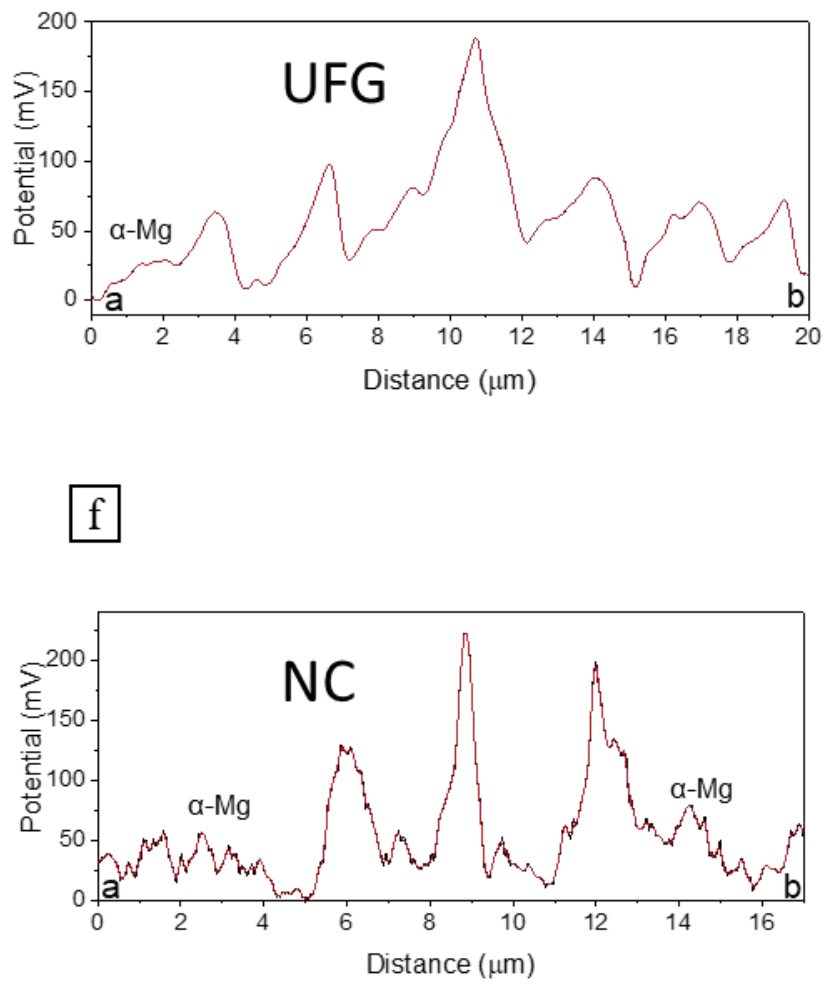

Fig. 8. 


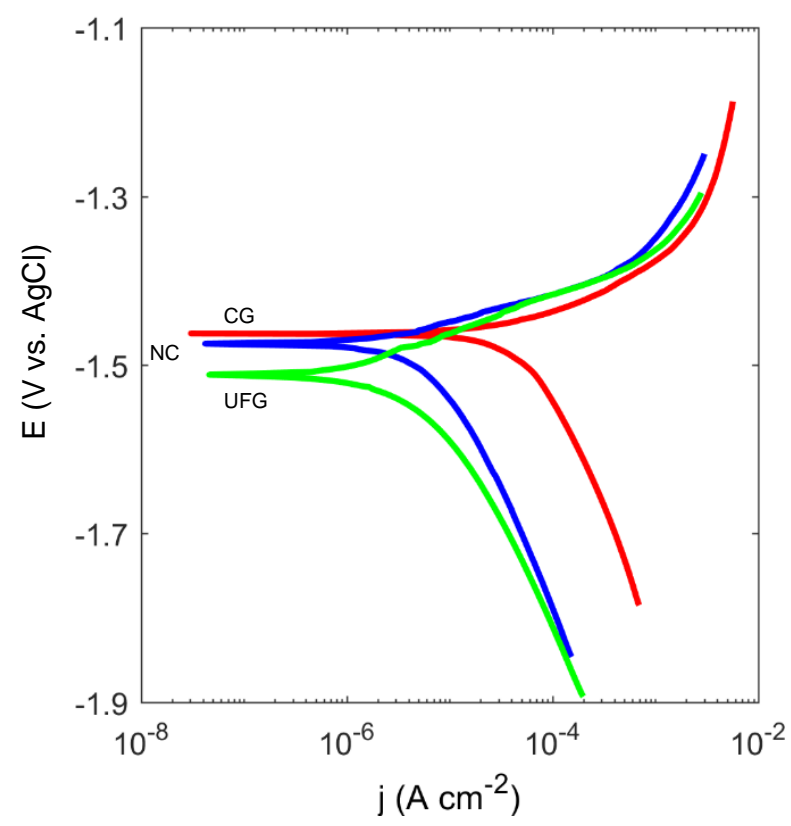

Fig. 9. 

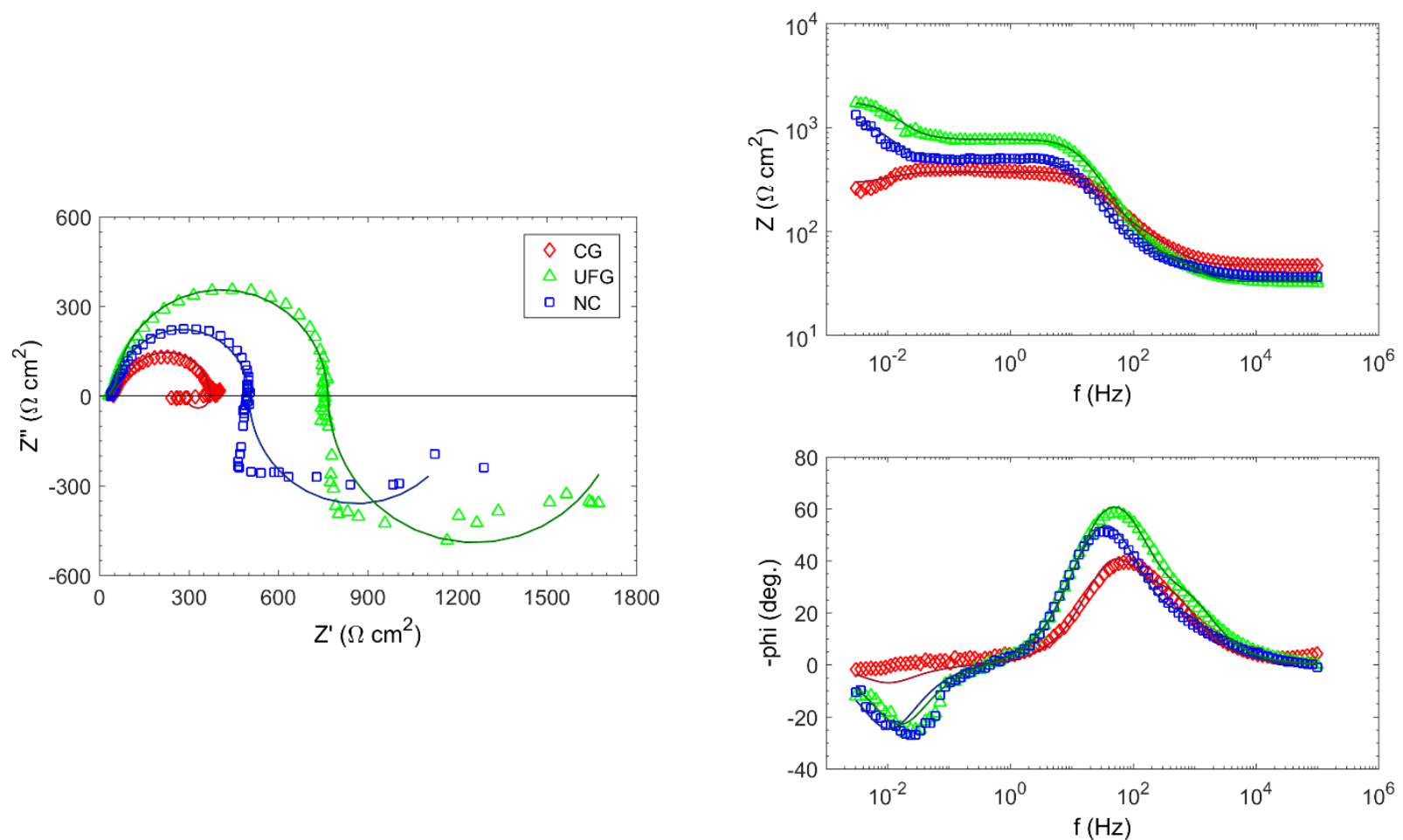

Fig. 10. 


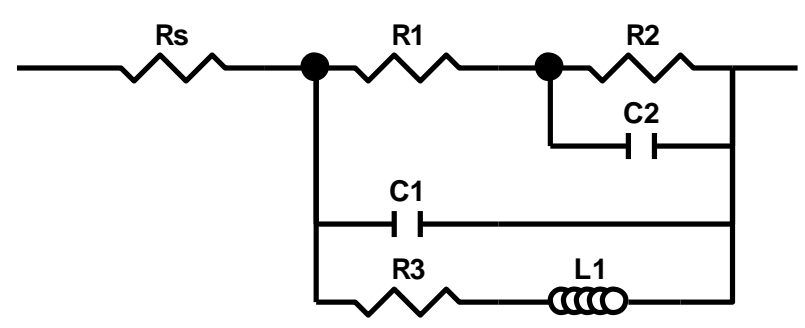

Fig. 11. 


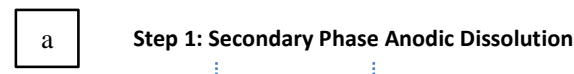

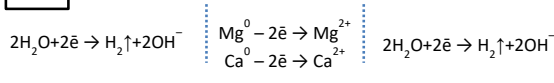

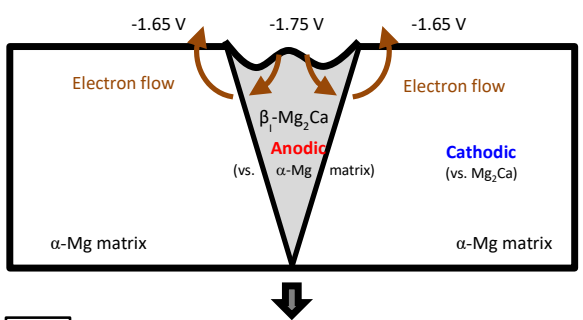

b Step 2: Hydroxide Precipitation

$\mathrm{Mg}^{2+}+2 \mathrm{OH}^{-} \rightarrow \mathrm{Mg}(\mathrm{OH})_{2} \downarrow+\mathrm{Cl}^{-}+\mathrm{H}_{2} \mathrm{O} \leftrightarrow\left[\mathrm{MeCl}(\mathrm{OH})^{-}\right]$

$\left[\mathrm{MeCl}(\mathrm{OH})^{-}\right]_{\text {ads }} \leftrightarrow \mathrm{MeClOH}+\mathrm{e}$

$\mathrm{Ca}^{2+}+2 \mathrm{OH}^{-} \rightarrow \mathrm{Ca}(\mathrm{OH})_{2} \downarrow \quad \mathrm{MeClOH}+\mathrm{H}^{+} \leftrightarrow \mathrm{Me}^{2+}+\mathrm{Cl}^{-}+\mathrm{H}_{2} \mathrm{O}$ $\mathrm{Me}=\mathrm{Mg}$ or $\mathrm{Ca}$

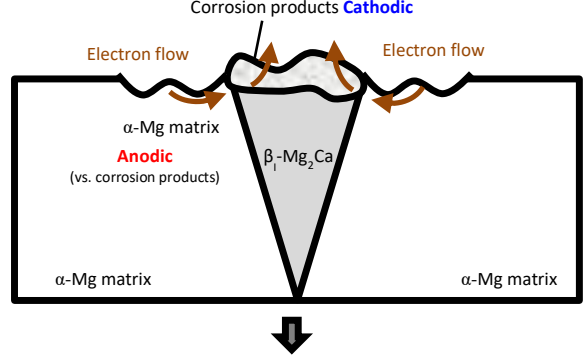

c Step 3: Corrosion Propagation (Step 1 + Step 2)

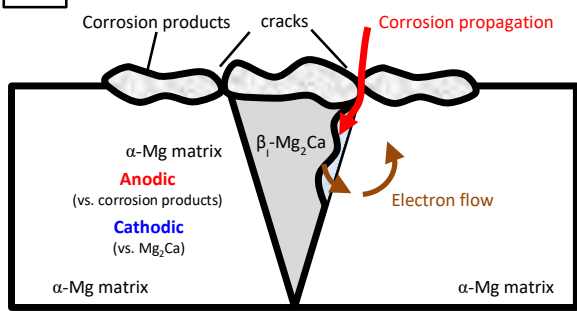

Fig. 12. 


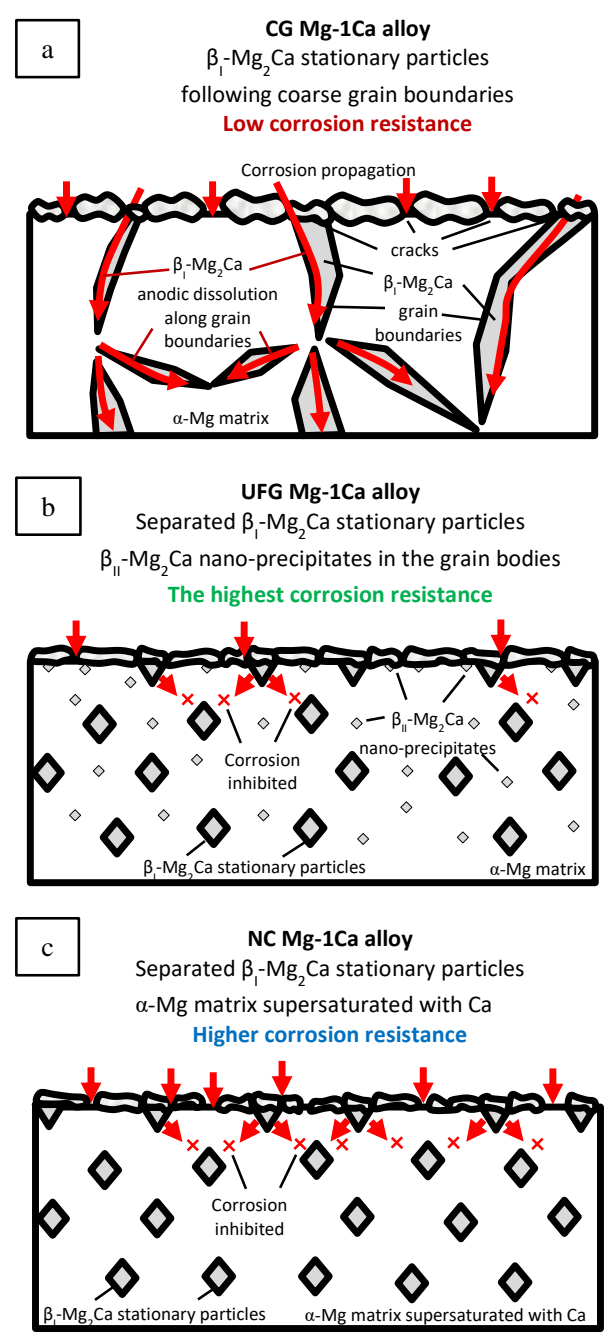

Fig. 13. 